Board of Governors of the Federal Reserve System

International Finance Discussion Papers

Number 527

October 1995

\title{
INTERNATIONAL COMPARISONS OF THE LEVELS OF UNIT LABOR COSTS IN MANUFACTURING
}

\author{
Peter Hooper and Elizabeth Vrankovich
}

NOTE: International Finance Discussion Papers are preliminary materials circulated to stimulate discussion and critical comment. References in publications to International Finance Discussion Papers (other than an acknow'ledgment that the writer has had access to unpublished material) should be cleared with the author or authors. 


\begin{abstract}
Comparing absolute levels of unit labor costs across countries entails translating labor compensation rates and productivity measured in national currencies into a common currency (e.g., U.S. dollars). Compensation rates are translated using market exchange rates and productivity is translated using relative output price levels. This paper focuses on the estimation of relative output price levels. Two approaches have been used, one based on relative unit value:s and the other on expenditure PPPs. We use primarily the latter approach and extend earlie-: work in this area by adjusting expenditure PPPs for biases introduced by indirect taxes, distribution margins, and trade prices. We compute for each of the G-7 industrial countries unit labor cost levels in U.S. dollars for total manufacturing and for various subsectors of manulacturing. Our estimates suggest that in 1995, U.S. unit labor costs were substantially below those in Japan and Germany, somewhat below those in France and the United Kingdom, and very similar to those in Canada and Italy. The cross-country differences we find are somewhat larger than--albeit qualitatively similar to--those obtained using the unit value approach.
\end{abstract}




\title{
International Comparisons of the Levels of Unit Labor Costs in Manufacturing
}

\author{
Peter Hooper and Elizabeth Vrankovich ${ }^{1}$
}

\section{Introduction and Summary}

Wide swings in nominal exchange rates among the currencies of industrial countries over the past two decades have produced substantial shifts in the relative costs of production in manufacturing across these countries. While movements over time in relative costs are monitored fairly intensively by various national and international statistical agencies, less is known about the comparative absolute levels of these costs at any given point in time. This paper presents estimates of unit labor cost levels for G-7 major industrial countries.

Measurement of the comparative levels of labor costs is of interest for a variety of possible reasons. First, they provide a summary statement of a key element in a country's internatic nal cost competitiveness. Researchers ranging from Stern (1962) to Golub (1994) have found that differences in unit labor cost levels influence the relative export performance, across industries, of major industrial countries. Second, to the extent that prices of tradable goods

${ }^{1}$ This paper was prepared for the festschrift conference, "Quiet Pioneering: Robert M. Stern and His International Economic Legacy," Ann Arbor, Michigan, November 18-20, 1994. The authors are members of the staff of the Board of Governors of the Federal Reserve System. The views presented here are our own and do not necessarily reflect those of the Board of Governors or other members of its staff. We thank Dirk Pilat and Bart van Ark for their detailed commentis on an earlier draft. We have also benefitted from comments and suggestions by Martine [)urand, Christopher Kask, Catherine Mann, Arthur Neef, J. David Richardson, Frank Stafford, Ted Truman, Andrew Wyckoff, and participants at the conference in Ann Arbor and a workshop in the Division of International Finance at the Federal Reserve Board. Finally, we thank the Bureau of Labor Statistics, the OECD, the World Bank, and the IMF for their assistance: with the data used in this paper, and we thank Simona Boata, Maya Larson, and Wilbur Maxino for their research assistance. 
across countries converge over time, significant differences in the levels of production costs provides some indication of the possible path of exchange rates and/or domestic cost levels in the longer term. In support of this view, various studies, including Frankel (1986), Edison (1987), Boucher Breuer (1994), Froot and Rogoff (1995), and Wei and Parsley (1995), have found considerable evidence that real exchange rates revert to their historical means over long periods of time. Third, cost differentials may also have implications for the locat on of production facilities and the flow of direct investment as firms seek to minimize their costs of production globally.

Over the years, a variety of researchers (listed explicitly in Section II below) have striven to measure the comparative levels of unit labor costs in manufacturing among the major industrial countries. Data on comparative levels of the numerator of unit labor cosits are readily available across countries since compensation rates can be translated from local currencies to common currency units using nominal exchange rates. The challenge in this line of research is translating the denominator of unit labor costs (productivity or output levels) acrosis countries into common currency units. To do so, one needs measures of relative national price levels specific to manufacturing, which can differ widely from nominal exchange rates. Two approaches have been pursued in the computation of such relative price levels or cutput price ratios. One approach has been to employ unit values ratios (UVRs) constructed from detailed census of manufactures data. The second approach has been to employ expenditure purchasing power parities (EPPPs) produced by the UN International Comparison Project (anid more recently by Eurostat and the OECD). As the Bureau of Labor Statistics and others have noted, both approaches have their drawbacks. The present paper focuses primarily on the second (or 
EPPP) approach and attempts to correct for the more important conceptual and empirical problems underlying that approach. We also compare our results with recent estimates that are based exclusively on the first (or UVR) approach.

We begin in Section II by describing and comparing the methodology underlying the two approaches and outlining our adjustments to correct for deficiencies in the EPPP approach. These adjustments pertain to correcting the EPPPs for factors that cause them to deviate from relative output prices (i.e., cross-country differences in distribution margins, indirect tax rates and the influences of import and export prices).

In Section III we compute output prices ratios for the United States vis a vis each of the other G-7 countries (Japan, Germany, France, Italy, the United Kingdom, and Canada) for total manufacturing and for each of five major subsectors of manufacturing starting with expenditure purchasing power parities for 1990. The EPPPs indicate that in recent years, final expenditure prices for goods have been significantly higher in Europe and Japan than in the United States. Conventional wisdom holds that these price differences have reflected, to a significant degree, higher indirect taxes and less efficient distribution systems in these countries than in the United States. We find that after adjusting expenditure prices for these and other factors, our estimates of output price levels in Japan and Europe show an even greater premium over the U.S. price level than is the case for expenditure prices. Contrary to the conventional wisdom, recent research has shown distribution margins to be higher in the United States than in other major industrial countries on average; we find that differences in net indirect tax rates and other factors that affec: the spread between expenditure prices and output prices also appear to be larger on balance in the United States than in other major induscrial countries on average. 
In Section IV, we present and analyze data on the comparative levels of labor productivity, compensation, and unit labor costs across countries and industries and compare our results with those reported in other recent studies. Using the output price ratios de rived in Section III, we compute productivity level estimates that show that in 1990 U.S. productivity in total manufacturing was significantly higher than that in other G-7 countries. Since U.S. compensation rates were about in line with average rates abroad at that time, U.S. unit labor costs were significantly below those in other G-7 industrial countries on average. When extrapolated to mid-1995 using indexes of domestic unit labor costs and nominal $\epsilon$ :xchange rates, we find that U.S. manufacturing unit labor costs were about 45 percent below those in Germany and 50 percent below those in Japan. Differences with other G-7 countries were a good deal smaller.

Our results show the relative level of U.S. productivity to be somewhat higher and the relative level of U.S. unit labor costs to be somewhat lower than estimates based cn the UVR approach. However, estimates based on both approaches find the level of manufarturing unit labor costs in the United States currently to be well below those in Japan and Gerrnany. Our analysis of differences in productivity, compensation and unit labor costs among clifferent subsectors of manufacturing suggests that within Japan, productivity is relatively low and unit labor costs correspondingly high in the food and textiles subsectors, and vice versa in the machinery, basic metals and chemicals industries. In Europe and the United States, textiles and apparel stands out as a low-productivity, high-unit labor subsector, but food and beverages are just the opposite--relatively high productivity and low unit labor costs.

Our conclusions are presented in Section V. 


\section{International Comparisons of Labor Cost Levels: Methodology.}

The simplest basis for comparing the levels of labor costs across countries is the rate of nominal compensation $(\mathrm{C})$ per worker or per hour worked $(\mathrm{H})$. Because differences in compensation rates across countries tend to reflect differences in labor productivity, however, the preferred basis for cross-country comparison of labor costs is unit labor costs (ULC), defined als total labor compensation per hour, divided by productivity, or total output per hour:

$$
\text { (1) } \quad U L C=\frac{C / H}{O / H}=\frac{C}{O}
$$

where

$$
\begin{aligned}
& \mathrm{C}=\text { compensation, measured in nominal currency units } \\
& \mathrm{O}=\text { output, measured in real terms (at prices in some base period) } \\
& \mathrm{H}=\text { total number of hours of labor input needed to produce } \mathrm{O} .
\end{aligned}
$$

\section{Conversion to Common Currency Units}

The key methodological issue underlying intercountry comparisons of labor costs is how to translate: the costs calculated for individual countries into comparable or common-currency units. Noninal compensation in different countries can readily be translated into a common currency using nominal market exchange rates. ${ }^{2}$ However, nominal exchange rates are not

${ }^{2}$ The use of nominal exchange rates to translate compensation levels into a common currency is appropriate from a "cost" perspective--for example, from the perspective of a firm or investors comparing current levels of labor costs across countries. From a welfare perspective (i.e., when comparing the command of labor compensation over expenditure on goods and services), it may be more appropriate to translate compensation at expenditure PPPs (defined 


\section{$-6-$}

appropriate for translating the values of outputs into common currency units because they may differ widely from the relative local-currency prices of those outputs (which we refer to henceforth as the output price ratio or OPR). ${ }^{3}$ To take an example, if the local output price of a unit of a particular manufactured good in Japan in some base year is 400 yen and the output price of a comparable product in the United States in the same year is two dollars, the OPR for that product is $400 / 2$ or 200 . The nominal exchange rate may be quite different, say 100 yen per dollar; moreover, nominal exchange rates tend to be much more variable over time than output price ratios.

Non-U.S. unit labor cost for industry or commodity category $i$ and country $j$ are thus translated into dollars as follows:

$$
\text { (2) } U L C_{i j}^{\$}=\frac{C_{i j} / E R_{j}}{O_{i j} / O P R_{i j}}
$$

where

$$
\begin{aligned}
\mathrm{ER}_{\mathrm{j}}= & \text { country j's nominal dollar exchange rate (expressed in terms units of } \mathrm{j} \text { 's currency } \\
\text { per dollar) } & \\
\mathrm{OPR}_{\mathrm{ij}}= & \text { the ratio of country j's average local-currency price level for the output of } \\
& \text { industry i to the average dollar price of U.S. output for that industry. }
\end{aligned}
$$

below). The focus of the current paper is on the cost side.

${ }^{3}$ The tendency for nominal exchange rates to diverge widely from movements over time in the ratios of domestic price levels (whether for nontradables or tradables) has been well established empirically. See, for example, Turner and Van't dack (1993). 
In terms of the above example, if the market exchange rate of 100 were used instead of the OPR of 200 to translate Japanese output into dollars, that output would be overstated by a factor of two and the level of Japanese unit labor costs in dollars would be understated by a factor of two. Note that equation 2 refers to a point in time, with output measured in current prices at that point in time. A time series of the level of country $j$ 's unit labor costs in dollars can then be derived by linking this observation to an index of country j's unit labor costs in dollars, where the underlyirig output or productivity index is measured at constant prices for the same base period.

\section{The UVR Approach}

All of the components of equation 2 except $O P R_{i j}$ are readily available across countries. Two different approaches have been used to compute OPRs specific to manufacturing. One approach, labeled the "unit value ratio" or UVR approach, is to estimate local-currency price levels (in the countries whose output levels are being compared) with unit values. The unit values are computed by dividing the value of manufacturing output at the industry or subindustry level by measures of the quantities of those outputs (tons of steel, pairs of shoes, and so on) derived from each country's census of manufactures. This approach has been used by a variety of researchers. Paige and Bombach (1959) computed UVRs to compare productivity levels in the U.K. and U.S. manufacturing sectors in the 1950s; this work formed the basis for Stern's (1962) examination of the influence of differences in unit labor cost levels on the relative export performance of U.S. and U.K. manufacturing industries. Smith, Hitchins and Davies (1982) upclated Paige and Bombach's estimates and extended them to include a U.K.-German comparison in the 1970s. O'Mahony (1992) has made a U.K.- German comparison using this 
methodology with more recent (1987) data. ${ }^{4}$ The most prominent work in this area over the past decade has been pursued by the International Comparison of Output and Productivity (ICOP) project of the University of Groningen (Netherlands). Maddison and van Ark (1994) and van Ark (1993) provide overviews of the project. Van Ark and Pilat (1993) and Pilat and van Ark (1994) report UVR-based price level and productivity comparisons between the United States and both Japan and Germany for 1987 and 1990. Van Ark (1992) reports U.S.-U.K. comparisons for 1987, and van Ark and Kouwenhoven (1994) do the same for U.S.-French comparisons.

One drawback to the UVR approach is the difficulty in matching the quantity $\mathrm{units}$ of output across countries. Such difficulties arise because of differences across countries in product definitions, product qualities, product mixes at the individual industry level, and units of quantity measurement. UVRs that have been computed in the ICOP project for the United States vis a vis four other major industrial countries (Japan, Germany, France, and the United Kingdom) are based on products accounting for less than one-fourth of the value of total manufacturing output (ranging from 15 percent for U.S.-French comparisons to 24 percent for U.S.-German. comparisons). Moreover, the coverage tends to be higher for more homıgeneous and less technologically sophisticated product categories, such as food and textiles, anc lower for the more sophisticated categories, such as machinery and equipment.

Another drawback to the UVR approach is that unit values have generally proven to be inferior indicators of actual price movements. As noted by Lichtenberg and Griliches (1989),

${ }^{4} \mathrm{O}$ 'Mahony also uses the EPPP approach (described further below) for some sectors where UVRs could not be obtained. 
producer price indexes have proven to be more reliable measures of U.S. output prices than unit values based on the census of manufactures. The methodology underlying the construction of expenditure purchasing power parities (discussed below) is substantially closer to the construction of price indexes than the methodology underlying unit values.

\section{The EPP]? Approach}

The second approach to estimating output price ratios has been to employ expenditure purchasing power parities (EPPPs) as proxies. The EPPPs are those for total GDP and disaggregated expenditure components that have been compiled during the past four decades by the U.N. International Comparison Project and more recently Eurostat and the OECD. Some researchers, for example Dollar and Wolff $(1988,1993)$ and Golub (1994), have simply used the aggregate EPPPs for total GDP as proxies for manufacturing OPRs. ${ }^{5}$ Others have attempted to refine these proxies by computing weighted averages of disaggregated EPPPs specific to manufactured goods categories. Prais (1981) used this technique to compare manufacturing output in the United States, Germany and the United Kingdom in the 1970s. Roy $(1982,1987)$ did much the same for a wider set of countries in 1975 and 1980, as did Hooper and Larin (1989) for the ten major industrial countries and Turner and Van't dack (1993) for a smaller set: of countries during the 1980 s.

As has been noted perhaps most prominently by the Bureau of Labor Statistics (see for example Neef and Kask (1993)), the use of EPPPs as proxies for manufacturing output price ratios has :everal potentially significant drawbacks. First, expenditure (or purchaser) prices

${ }^{5}$ The OECD also uses this procedure in its International Sectoral Database to translate manufacturing outputs at the industry level across countries into common currency units. 
reflect cross-country differences in wholesale and retail distribution margins and transportation costs, while output (or producer) prices do not. Second, expenditure prices include incirect taxes and subsidies (which can vary across countries), while output prices do not. Third, expenditures include imports (which do not affect output prices directly), while they exclude export:s, which are reflected directly in output prices. To the extent that import and export prices differ from the prices of domestic output that is sold domestically and trade in the sector in question is imbalanced, expenditure prices will differ from domestic output prices. Finally, EPPPs pertain to final expenditures and do not lend themselves to the comparison of price levels for sectors that produce intermediate rather than final products.

Initial attempts have been made to deal with some of these problems. Specifically, Jorgenson and Kuroda (1992) used EPPPs for the mid 1980s to compare U.S.-Japanes€ manufacturing outputs and adjusted the EPPPs for trade and transportation margins and indirect taxes. Some work has begun at the OECD to adjust EPPPs for indirect taxes and the influences of import and export prices for a wider set of countries.

In this paper we adopt primarily the second or "EPPP" approach and attempt to deal directly with its major shortcomings by making adjustments to the EPPPs for indirect laxes and subsidies, distribution margins, and the influence of import and export prices. In doing so, we extend the scope of earlier published estimates using this approach by making use of deta on EPPPs that have recently been made available by the World Bank at a more detailed level of disaggregation than was the case previously. ${ }^{6}$. We also make an initial attempt to fill irl some of

${ }^{6}$ The International Economics Department has constructed spreadsheets containing detailed data from the U.N. International Comparison Program for 1975, 1980, 1985, ard 1990. These spreadsheets are available on the World Bank's "STARS" diskettes and are described in 
the gaps in this approach with respect to intermediate goods prices by using UVR-based estimates for the basic metals industry.

\section{Computation of EPPPs}

Our starting point is the EPPPs for 101 final expenditure categories from the ICP project for each of six major industrial countries (Canada, France, Germany, Italy, Japan, and the United Kingdom) vis a vis the United States. The EPPPs for the 101 "basic heading" categories (e.g., bread, besf, poultry), in turn, reflect averages of EPPPs for up to 500 (or roughly 5 per category) individual products or "items". First, we aggregate the basic-heading EPPPs into five manufacturing subsectors. ${ }^{7}$ The weights used in this first level of aggregation are the shares of expenditures on the basic heading categories $(\mathrm{k})$ in the total expenditures across all seven countries $(\mathrm{j})$ on the manufacturing subsector $(\mathrm{I})$. This weighted average is written:

$$
\text { (3) } \quad E P P P_{i j}=\sum_{k=1}^{n} \frac{\sum_{j=1}^{\prime} E_{i j k}}{\sum_{i=1}^{7} \sum_{i=1}^{n} E_{i j k}} E P P P_{i j k}
$$

where

$E_{\mathrm{ijl}}=$ the value of expenditures in dollars (translated from local currencies using the EPPPs) in country $\mathrm{j}$ on the basic heading category $\mathrm{k}$ in subsector $\mathrm{I}$.

World Bank (1993).

${ }^{7}$ The subsectors include (1) food, beverage, and tobacco products, (2) textiles, apparel, and footwear, (3) chemicals, petroleum refining, and rubber and plastic products, (4) machinery, equipment, and fabricated metal products, and (5) other manufactures, which include, among other products, paper and printing, wood and furniture products, and non-metallic mineral products. 


\section{Adjustment for Distribution Margins}

Second, we adjust the EPPPs for differences in distribution margins. Given that the EPPP $_{i j}$ is defined as the ratio of expenditure prices (PE) in country $\mathrm{j}$ relative to those in the United States:

$$
\text { (4) } E P P P_{i j}=\frac{P E_{i j}}{P E_{i U S}}
$$

the EPPP adjusted for distribution margins $\left(\delta_{i}\right)$ is defined:

$$
\text { (5) } \quad E P P P_{i j}^{m}=\frac{P E_{i j} /\left(1+\delta_{i j}\right)}{P E_{i U s} /\left(1+\delta_{i U S}\right)}=\frac{1+\delta_{i U s}}{1+\delta_{i j}} E P P P_{i j}
$$

where

$$
\begin{aligned}
\delta_{i j}= & \text { the combined wholesale and retail distribution markup over producer prices for } \\
& \text { subsector } i \text { in country } \mathrm{j} .
\end{aligned}
$$

To the extent that distribution margins in other countries exceed those in the United States, their EPPPs adjusted to exclude those margins will be less than the unadjusted EPPPs.

\section{Adjustment for Net Indirect Taxes}

Third, we make a similar adjustment to the $\mathrm{EPPP}_{\mathrm{ij}}$ for the influence of indirect taxes and subsidies: 
(6) $\quad E P P P_{i j}^{*}=\frac{1+\left(T_{i U S}-S_{i U S}\right) / V A_{i U S}}{1+\left(T_{i j}-S_{i j}\right) / V A_{i j}} E P P P_{i j}^{m}$

where

$T_{i j}=$ indirect taxes collected from subsector $i$ in country $j$,

$S_{i j}=$ subsidies received by subsector $i$ in country $j$,

$V^{\prime} A_{i j}=$ value of output (value added) in subsector $i$, country $j$.

As with the distribution margins, the adjustment for taxes and subsidies is made both for country $\mathrm{j}$ and for the United States. To the extent that indirect taxes net of subsidies are greater in other countries than in the United States, the PPP in terms of expenditure prices will be greater than that in terms of output prices (or in terms of expenditure prices net of taxes and subsidies).

\section{Adjustment for International Trade}

Fourth, we adjust the EPPP*s for the net influence of import and export prices on the difference between expenditure and output prices. This adjustment begins with the definition of the domestic expenditure price index (net of indirect taxes and subsidies and distribution margins--PE*) as a weighted sum of the price of imports (PM) and the price of domestic output that is sold domestically (PD):

(7) $P E^{*}=\frac{M}{F^{*}} P M+\frac{E^{*}-M}{F^{*}} P D$

where

$$
\begin{aligned}
& M[=\text { imports } \\
& E^{*}=\text { domestic expenditure net of indirect taxes and subsidies and distribution margins. }
\end{aligned}
$$


Solving for PD, we get:

$$
\text { (8) } P D=\frac{E^{*}}{E^{*}-M} P E^{*}-\frac{M}{E^{*}-M} P M
$$

The price of total domestic output $(\mathrm{P})$ is defined as a weighted sum of the price of exported goods (PX) and PD:

$$
\text { (9) } \quad P=\frac{X}{O} P X+\frac{O-X}{O} P D
$$

where

$$
\begin{aligned}
& X=\text { exports } \\
& O=\text { total domestic output. }
\end{aligned}
$$

To solve for $\mathbf{P}$ in terms of $\mathrm{PE}^{*}$, we note that expenditures are equal to output plus impo:ts minus exports:

$$
\text { (10) } E^{*}=O+M-X
$$

And, we assume that for each category of goods, both imports and exports are priced at the average world price level (PW) where all prices are measured in a common currency (i.є., dollars):

(11) $P M=P X=P W$ 
Substituting (8), (10), and (11) into (9) and rearranging terms, yields:

$$
\text { (12) } \quad P=P E^{*}+\frac{X-M}{O}\left(P W-P E^{*}\right)
$$

Equation (12) indicates that the domestic output price will exceed the domestic expenditure price if the world price exceeds the domestic expenditure price and the country is running a trade surplus in the category of goods in question. In this case, the price of exports and imports will be above the price of domestic output sold domestically, and with exports being greater than imports, they will have a greater positive effect on the output price than imports will have on the expenditure price.

We define the "world" price level (in dollars), as the output-weighted average of each country's expenditure price level in dollars (net of indirect taxes and subsidies) for manufacturing subsector in question:

$$
P W_{i}^{\$}=\sum_{j=1}^{7} \frac{V A_{i j} / E P P P_{i j}^{*}}{\sum_{j=1}^{7} V A_{i j} / E P P P_{i j}^{*}} * P E_{i j}^{\$}
$$

where each country's output in dollars was defined, at this stage, as value added in local currency (VA) divided by the adjusted expenditure PPP (or EPPP*). With the EPPP*s normalized to a U.S. price ( $\mathrm{PE}^{*}{ }_{\text {us }}$ ) level of 1.0, we derive the other countries' expenditure price 
levels in dollars as their EPPP*s divided by their nominal dollar exchange rates:

$$
\text { (13) } P E_{i j}^{\$}=\frac{E P P P_{i j}^{*}}{E R_{j}}
$$

Our output price ratio (OPR) for each country $\mathrm{j}$ is now derived as the ratio of $\mathrm{j}$ 's output price to the U.S. output price (or the ratio of PE*s adjusted for import and export price effects):

$$
O P R_{i j}=\frac{P_{i j}}{P_{i U S}}=\frac{P E_{i j}^{*}+\frac{\left(X_{i j}-M_{i j}\right)}{O_{i j}}\left(P W_{i}-P E_{i j}^{*}\right)}{P E_{i U S}^{*}+\frac{\left(X_{i U S}-M_{i U S}\right)}{O_{i U S}}\left(P W_{i}-P E_{i U S}^{*}\right)}
$$

Recall from our discussion of equation (12) that if country $\mathrm{j}$ is running a trade surplus in commodity category $\mathrm{i}$, and the world price exceeds its domestic price, its output price will exceed its expenditure price. In this case, country j's OPR will exceed its EPPP* so long as the U.S. output price exceeds the U.S. expenditure price by a proportionately smaller amount than is the case for country $\mathrm{j}$.

Our adjustment for import and export prices is admittedly based on several "heroic" assumptions. First, we have assumed that each country is a price-taker in the world market. That is, we have assumed that each country prices its exports at the world market price and pays for its imports at the world market price. Several of the countries we consider (most notably the United States) are large enough to have some degree of control over the prices of their inaports 
and exports. Second, we have abstracted from tariffs and non-tariff barriers, which may cause the domestic price of imported goods to differ from the world price level. Third, as a proxy for the "worlc:" price level, we have taken the average price level for the G-7 countries. Trade among these seven countries actually accounts for only about half of their total international trade, and the actual world price level could differ significantly from the one we have assumed. For these reasons, we will consider in the empirical section that follows the sensitivity of our estimates io plausible alternative assumptions about the behavior of import and export prices.

One final conceptual problem with the EPPP methodology is that the underlying final goods prices are not tailored to value added at the manufacturing subsector level--that is, they do not net out the cost of raw materials or intermediate inputs from other sectors. This problem is less serious the more highly aggregated the level of analysis; partly for this reason we have chosen to work only with relatively aggregated subsectors of the manufacturing sector. ${ }^{8}$ As noted by Van Ark (1993) and Jorgenson (1993), the UVR methodology suffers from the same drawback."

\section{Empirical Estimation of the OPRs}

${ }^{8}$ In principle, even at the level of total manufacturing a potential bias is introduced, to the extent that the prices of raw material and energy inputs (excluding those, like refined petroleum products, that originate in the manufacturing sector) as well as service-sector inputs differ across countries. In most cases, raw material prices tend to be priced more uniformly across countries than other, less homogeneous goods. However, service sector inputs are potentially more problematic as they are much less likely to be priced uniformly across countries.

${ }^{9}$ It is generally argued that on theoretical grounds (i.e., from the standpoint of a production function approach), gross output is preferred over value added as a basis for comparing productivity across countries. However, the only data that are readily available for outputs on a roughly comparable basis across countries (including the OECD's International Sectoral Database, and the U.S. Bureau of Labor Statistics unit labor cost database) are limited to value added data obtained from national income accounts. 


\section{The EPPPs}

Our derivation of OPRs for total manufacturing and by major manufacturing sector began with the averaging of ICP expenditure PPPs (EPPPs). We used the 1990 "EKS" PPPs that were published in summary form in OECD (1992) and were subsequently made available at the more detailed level in World Bank (1993). ${ }^{10}$ The goods categories that we selected for each manufacturing subsector are shown in Table 1. The food, beverages and tobacco products subsector included over 40 basic heading entries, the machinery and equipment subsector over 30 entries and the other three subsectors 8 to 10 entries each. There were no entries for basic metals, which are primarily intermediate goods. Table 1 also shows the EPPPs for each of the basic heading entries across countries (the $\left.\operatorname{EPPP}_{\mathrm{ijk}} \mathrm{s}\right)$. The two right-hand columns of the table show total G-7 expenditures (in dollars) on those goods categories and each category's share in

${ }^{10}$ The EKS (Elteto-Koves-Szulc) method pertains to the way in which individual commodity PPPs are aggregated up to PPPs for total GDP. The EKS method gives roughly equal weight to the pattern of expenditures in all the countries being compared (in this case the $\mathrm{OECD}$ countries). Its main attraction is that it allows for consistent cross-country or thirdcountry comparisons of relative price levels. Its main weakness is that it does not allow' for arithmetic adding up of individual expenditure components to total GDP in any given country. The primary competing method of aggregation is the Geary Khamis (GK) method, which employs expenditure weights that are specific to any two countries that are being compared. This method does allow for adding up of components, but it effectively gives greater weight to larger countries and entails less consistency in third-country comparisons. That is, the PPPs between countries A and $B$ and between countries $A$ and $C$ may not yield a consistent comparison for countries $B$ and $\mathrm{C}$ if country A's expenditure pattern differs significantly from those of the other two. The particular method of aggregation used for the expenditure PPPs is not of central concern to our own analysis because we begin with PPPs at a relatively low level of aggregation. Our own method of aggregation, which entails using average expenditure (and output) weights for the group of seven countries considered lies somewhere between these two methods, and may be closer in spirit to the EKS methodology, tending to increase the cross-country comparability of our results. As we will see, however, the different aggregation methods do not make a significant difference to our results. See Kravis, Kennesy, Heston, and Summers (1975) for a detailed description of--and discussion of the pros and cons of--the alternative PPP aggregation methods. Kravis et. al. also describe the "Walsh" method, which is essentially the one used here. 
the total expenditures for the particular manufacturing sector. The expenditure shares were the weights used to compute the $\operatorname{EPPP}_{\mathrm{ij}} \mathrm{s}$ defined in equation (3), and the computed values of the $\mathrm{EPPP}_{\mathrm{ij}} \mathrm{s}$ are shown at the bottom of each manufacturing sector group in the table.

The level of disaggregation we are working with captures some but by no means all of the dispersion of PPP levels across commodity categories. In the case of Japan, for example (the first colunn of numbers in the table), $\operatorname{EPPP}_{\mathrm{ij}} \mathrm{s}$ range from a high of 281 yen per dollar for food, beverages and tobacco, to a low of 190 yen per dollar for machinery and equipment (169 excluding office machinery). The individual $\operatorname{EPPP}_{\mathrm{ijk}} \mathrm{s}$ within these sectors range even more widely. For example, in the food sector, beef and veal show a high of 549 yen per dollar, while seafood ranges as low as 133 yen per dollar. And, in the machinery and equipment sector, some household appliances range as high as 300 to 400 yen per dollar, while the EPPPs for transporta:ion equipment are generally in the 100 to 150 range.

The EPPPs for office machinery (which include computers) look suspect and could reflect artificial differences in price measurement practices across countries. The 1985 EPPPs for the same category were only about one tenth as large. It would appear that the 1990 EPPPs were derived by extrapolating in 1985 EPPPs with relative deflators for office machinery. The United States measures movements in computer prices over time with a hedonic index that shows a st:ong downward trend. Most other countries do not use this methodology, and their computer price indexes tend to show increases or only moderate declines over time. This difference in price measurement practices could introduce a significant bias into our estimation 
of the OPRs for machinery and total manufacturing. " As indicated in the table (at the botton of the machinery subsector), when office machinery is excluded from that subtotal, the EF'PP is lowered by about 10 percent for each country. Given the weight of machinery in total manufacturing, this lowers the OPR for total manufacturing by about 5 percent in most of the countries. In light of this potential bias, we decided to exclude office machinery (which accounted for 2-1/2 percent of total G-7 expenditures on machinery and equipment in 1990) from our EPPP calculations.

The $\operatorname{EPPP}_{\mathrm{ij}} \mathrm{s}$ are presented again in Table 2, which shows our derivation of OPRs from the EPPPs. This derivation can be seen more clearly when the EPPPs are translated to expenditure price (PE) levels by dividing through by the 1990 nominal exchange rates. The corresponding price levels, indexed to a U.S. PE of 1.0, are shown in Table 3. The foreign PEs in 1990 were uniformly higher than the U.S. PEs. While it is difficult to generalize, this difference tended to be maximized in the textile and apparel sector for most countries and in the food sector for Japan, where expenditure prices were nearly double the U.S. level.

Averaging across sectors, Italy showed the largest expenditure price premium over the U.S. price level for total manufacturing (at more than 50 percent), while Canada and the United Kingdom showed the smallest. ${ }^{12}$ The weights used to compute the averages for total manufacturing are the sector shares in total G-7 output, shown in the bottom panel of Table 4 .

\footnotetext{
${ }^{11}$ The problems that computer prices pose to international comparisons of outpu: and productivity are discussed in greater detail in the next section and by Wyckoff (1993).

${ }^{12}$ EPPPs were not available for basic metal industries; to compute weighted averages for total manufacturing we used the ICOP UVRs for basic metals as substitutes wherever they were available. When UVRs were not available (as in the case of Italy and Canada), we used the EPPPs for machinery.
} 
Machinery and equipment has the largest output weight, at about 45 percent, while the textiles and apparel sector has the smallest, at 4 percent. This is generally true across countries, as indicated ir the upper panel of the table, although textiles and apparel figure much more importantly in Italian output than in that of other countries. The table also shows, for comparison, the shares of the manufacturing sectors in total G-7 expenditures in 1990. The shares of fcod, textiles, and petroleum (where the G-7 countries are net importers on average) are larger in expenditures than in output, while the opposite is true for machinery and other manufactured products (where these countries are net exporters on average).

\section{Adjustment for Distribution Margins}

Our first adjustment to the expenditure prices was to remove wholesale and retail distribution margins. Estimates of these margins for total manufacturing were obtained from a series of recent papers written as part of an OECD project to analyze the distribution systems of the major industrial countries. These margins, which include the total value added (the cost of labor, other inputs and profit margins) of the distribution sectors, excluding transportation costs and indirect: taxes, are shown in Table 5. One surprising result from these studies is that total wholesale plus retail margins in the United States, which is typically thought to be have a relatively e:ficient distribution system, were found to be at the high end of the range for these countries (roughly 40 to 60 percent in 1987), while margins in Germany, the United Kingdom, and especially Japan were found to be lower. ${ }^{13}$ These results are corroborated by a separate

\footnotetext{
${ }^{13}$ The margins were shown to be relatively stable over time, which suggests that application of data on margins for 1987 (the latest year available) to our calculation of OPRs in 1990 probalbly is not a significant source of error. Retail margins were not reported for Italy or Canada. We used the U.S. margins for Canada and an average of the French and German margins for Italy.
} 
study by Ito and Maruyama (1991), whose results are also reported in the table, and an independent study by Nishimura (1993). ${ }^{14}$

The OECD project unfortunately did not provide details on margins at the manufacturing subsector level consistently across countries. In our analysis, therefore, we have made adjustments at the subsector level with the average margins for total manufacturing. Bzised on U.S. input-output data (U.S. Department of Commerce (1994)), total margins tend to be: substantially higher than average in the area of consumer expenditures (as high as 75 to 100 percent on food, apparel and footwear, and many consumer durables, for example) and noticeably lower than average for producer durables. To the extent that these differences across subsectors vary across countries, our comparisons at the subsector level may be biased. Our estimates may also be biased by the absence of adjustment for differences in domestic transportation margins, although the bias in this case is likely to be small. ${ }^{15}$

The effects of adjusting for distribution margins are shown by comparing the top two lines in each subsector panel of both Table 2 (compare the unadjusted EPPPs and the adjusted EPPPms) and Table 3 (compare the PEs and the PEms). When adjusted for distributior. margins, the price levels in Japan, Germany, and the United Kingdom relative to the United States (i.e., the EPPPms) are higher than on an unadjusted basis--in the Japanese case nearly 13

${ }^{14}$ Nishimura corrects for several statistical shortcomings in the OECD project's (Maruyama's) estimates for Japanese distribution margins. He also compares transportation margins across U.S. and Japanese industries using input-output data and finds these marcins to be both small (between 1 and 3 percent of final sales) and similar between the two countries.

${ }^{15}$ U.S. input-output data indicate that transportation costs typically are only about 2 to 3 percent of final sales--far less than wholesale and retail margins. (See U.S. Department of Commerce (1994).) Also, as noted above, Nishuimura has found that U.S. and Japanese transportation margins are similar in magnitude. 
percent hig,her.

\section{Adjustment for Net Indirect Taxes}

Our next adjustment was for indirect taxes and subsidies. Net indirect tax rates were computed as the difference between taxes paid and subsidies received in each subsector divided by subsectior value added--using data obtained from the OECD ISDB and OECD National Accounts publications. ${ }^{16}$ These net indirect tax rates are shown in Table 6. The OECD reports relatively large net indirect taxes for Japan, especially in the food sector ( 32 percent), and relatively low net rates for Italy (where sizable subsidies largely offset slightly more sizable tax collections). U.S. rates are about average. Across subsectors, net indirect tax rates tend to be highest for food and for chemicals (including petroleum products). Notable exceptions to this rule are France, where net indirect taxes on food are about zero, and Italy, where net indirect taxes on chemicals and petroleum are about zero.

The: effects of adjusting for taxes can be seen in Table 2 by comparing the EPPPms (unadjusted) with the EPPP*s (adjusted), and in Table 3 by comparing the PEms with the PE*s. This adjustment tends to reduce the relative price levels slightly in Japan, Germany and France (where net indirect tax rates are somewhat above U.S. rates on average)--downward adjustments are most pronounced for food and chemicals in Japan and Germany. The relative price levels in the other countries are raised slightly overall.

\section{Adjustment for International Trade}

Our final adjustment is for the prices of imports and exports. For this purpose we used

${ }^{16}$ In several cases data were not available for 1990, so we used data for 1989 and 1988 where necessary. Over the preceding ten years, net tax rates generally varied by less than 1 percentage point in each of these countries. 
trade balances expressed as a percent of value added (as reported in Table 7) and our ow'n computation of the "world price level", as defined in equation (12) above and reported in the far right-hand column of Table 3 . Recall that this adjustment will be greatest in cases whete both a country's trade imbalance and the deviation of its domestic price level from the world price level are greatest. The largest trade imbalances tend to occur in the textile and apparel sector: with most countries showing big deficits and Italy showing a big surplus. Also, Germany and Japan show large surpluses and Canada a large deficit in machinery and equipment. In most cases, subsector imbalances tend to be offsetting within countries and the imbalances for total manufacturing are generally a good deal smaller. As indicated by comparisons of the G-7 and single-country values of the $\mathrm{PE}^{*} \mathrm{~s}$ in Table 3 , deviations from the world price level (at 1'990 exchange rates) tended to be highest for textiles. Among countries, PE*s in Italy tended to be at the high end of the range and those in the United States at the low end.

The effect of the adjustment for international trade prices can be seen by comparing the EPPP*s and the OPRs in Table 2, as well as the PE*s and Ps in Table 3. The largest adjustments occur in the textile and apparel sector. For example, Japan, Germany, and France have lPE*s above the world price level, and since those countries run large trade deficits in textiles and apparel, their output prices are adjusted upward relative to their PE*s. The net result is an increase in the OPR relative to the EPPP* in Table 2. The United States too runs a trade; deficit in that sector, but with the U.S. expenditure price (adjusted for taxes and margins--PE*) below the world price level, the U.S. output price $(\mathrm{P})$ is adjusted down relative to $\mathrm{PE}^{*} .{ }^{17}$ In Italy's

${ }^{17}$ This result for the United States is somewhat counterintuitive. Why should a cciuntry whose output price is below the "world" price be running a large deficit in that sector? Part of the problem is that our measure of the world price level is limited to an average for G-7 countries. In 
case, however, despite a high $\mathrm{PE}^{*}$ relative to the world price level, $\mathrm{P}$ and OPR were adjusted downward because Italy runs a large surplus in textiles and apparel.

In the more important machinery and equipment subsector and for overall manufacturing, the adjustments for import and export prices were generally fairly small, either because of small trade imbalances or because of small deviations from the world price level.

Because of the strong (perhaps even heroic) assumptions underlying our adjustments for import and export prices, we also considered how the results would be affected if, (a) import and export prices fell midway between the world price level and the domestic price level, and (b) impcrt prices were at the world price level and export prices at the domestic price level. In the former case, to a rough approximation, the adjustment was cut in half and had little net effect, except in the textile and apparel sector. In the latter case, the result was to produce an even greater upward adjustment in the output prices of all the other G-7 countries relative to the United States.

\section{The Combined Adjustments}

The net effect of our adjustments to expenditure prices yields estimates of output prices that show, if anything, a greater premium of foreign price levels over U.S. price levels. As indicated at the bottom of Table 3, the PEs for total manufacturing in the foreign G-7 countries ranged between 22 an 52 percent above the U.S. level in 1990. And, as indicated in the bottom

the case of textiles and apparel in particular, this limitation probably overstate the level that would be derived if the production and prices of developing countries were taken into account. Nevertheless, a more accurate (i.e., lower) measure of world prices for purposes of this adjustment would not greatly affect our comparison of price levels, at least among the G-7 countries that run a trade deficits in this sector. This is because the greater upward adjustment of German and Japanese output prices, for example, would be largely offset by a smaller downward adjustment of U.S. output prices. 
panel of Table 8 (which shows the same data indexed to a U.S. output price level of 1.1)), foreign output prices ranged between 26 and 68 percent above the U.S. level. Table 2 shows that the largest positive differences between OPRs and EPPPs were in the textile and apparel subsector. The only cases where the OPRs fell below the EPPPs were for food in Germany and chemicals and petroleum in Germany and France (in all three cases, high indirect tax rates accourted for most of the net downward adjustment).

\section{Comparison of Alternative Measures of Relative Price Levels}

Table 2 also shows the ICOP unit value ratios (UVRs). ${ }^{18}$ A summary comparis on of our OPRs and the UVRs is presented in Table 9 (which shows the two measures and ratios of the OPRs to the UVRs). In most cases the UVR's fall noticeably below the OPRs--by as rnuch as 40 percent for total manufacturing in the case of Japan, and by between 10 and 15 percent for Germany, France and the United Kingdom. ${ }^{19}$

Two UVRs are shown for total manufacturing. The first is a weighted average using our G-7 output weights and arithmetic weighting procedure. The UVR*s are the weighted averages reported by van Ark and Pilat, et. al., using a geometric average with output weights specific to the two countries being compared. The two weighting schemes make very little difference at

\footnotetext{
${ }^{18}$ In the case of Japan and Germany UVRs were available for 1990; for the United Kingdom, we extrapolated UVRs for 1987 using relative value added deflators obtained from OECD national accounts data. Van Ark and Pilat used the same methodology to extrapolate their 1987 UVRs for Germany and Japan to 1990.

${ }^{19}$ Indeed, because of the way the UVRs were extrapolated from 1987 to 1990 (with unitvalue deflators), the numbers shown here may actually understate the difference between the OPRs and the UVRs. That is, because of differences in the measurement of computer prices in the United States (where they are falling rapidly) and the other countries (where they are relatively stable), the UVRs reported here are probably biased upward by between 5 and 10 percent for total manufacturing and between 15 and 20 percent for machinery and equipment.
} 
this level of aggregation, except possibly in the case of France.

Table 9 also shows the 1990 EKS PPPs for total GDP, which have been used by various researchers as proxies for relative manufacturing price levels. In the case of Germany and Japarı the PPPs are tolerably close to our OPRs (roughly within 5 percent); for the other couniries, however, the PPPs understate our OPRs by amounts ranging from 10 percent for France to 35 percent for Italy.

These comparisons, along with the large cross-country differences in absolute price levels for 1990 shown in Tables 3 and 8, may lead one to wonder about the "plausibility" of our results. Our ability to capture the prices of many intermediate goods only indirectly through their contribution to final product prices is a potentially important source of error. The difference between the OPR and UVR estimates is greatest for textiles and apparel, an area where: intermediate goods (which the UVR approach most likely captures better) figure importantly. At the same time, the OPR estimates are also generally significantly above the UVR estimates in the finished goods areas, where their coverage may well be superior. Moreover, several of the choices we made in constructing our adjustments--including the treatmient of import and export prices and the extrapolation of UVRs to 1990 with value added deflatiors--probably have had the net effect of understating the difference between the UVR estimates and our OPR estimates.

\section{Labor Costs: Data and Analysis}

In this section we present and analyze the comparative levels of unit labor costs and their components, output per hour and compensation per hour, in each of the G-7 countries for total manufacturing and each of the six subsectors described in the preceding section. The analysis 
includes comparison of our results with those of other studies.

\section{Productivity}

Data The output price ratios (OPRs) derived in the preceding section were used to translate output per hour for 1990 in each of the non-U.S. G-7 countries from local currency into dollars. The output data for total manufacturing and for the subsectors are value addec data from standardized national accounts as reported in the OECD International Sectoral Database (ISDB) and the OECD Annual National Accounts (1994). These sources contain sectcral data on nominal and real value added, compensation, employment, imports, exports, and net indirect taxes for many of the OECD countries. ${ }^{20}$ (The OECD National Accounts contain the most recent observations of the historical series we took from the ISDB.) We also substituted the recently revised U.S. gross product originating (GPO) data for the value added data found in the ISDB. ${ }^{21}$ The revised GPO data were only available for the 1977-1991 period. We extended the data for total U.S. manufacturing back to 1970 using the growth rates in the previous (unrevised) data series. ${ }^{22}$ For the United States, Japan, Germany and France, the value added in the national accounts is measured on a market-price basis rather than the preferable factor-cost basis. We used the net indirect tax data in the ISDB (updated where necessary) to convert market prices to

\footnotetext{
${ }^{20}$ See OECD (1988 and 1993) for a full description of the ISDB.
}

${ }^{21}$ Due to heavy criticism of its methodology for calculating real output for industry, the Bureau of Economic Analysis (BEA) suspended publication of its data in 1989 and be efforts to address some of the complaints. Lawrence (1991) provides a discussion of many of the criticisms of the data. See de Leeuw, Mohr and Parker (1991) and Parker (1993) for a full description of the improvements BEA made to the gross product originating data.

${ }^{22}$ To the extent that the other countries have not undertaken similar steps to improve their estimates of real output, additional biases to the comparability of results across countries could have been introduced by using the updated U.S. data. 
factor costs.

Data. on hours worked across countries and manufacturing subsectors were computed from subsectoral data on total employment from the ISDB (and the OECD National Accounts) and data on total hours worked in manufacturing provided by the BLS Office of Productivity and Technology. To estimate hours worked at the subsector level we multiplied hours worked in total manufacturing by the each subsector's share in total employment in manufacturing. ${ }^{23}$.

$\underline{\text { Results }}$ Our results for productivity, measured in terms of 1990 dollars per hour, are shown in the top panel of Table 10. The bottom two panels show observations for 1985 and 1980, whichı were extrapolated back using growth rates in real output per hour measured in constant local currency units. ${ }^{24}$ These data are presented in slightly different form in Table 11 , with productivity levels indexed to a U.S. level of 100. Movements in comparative productivity levels over time are shown more clearly in Chart 1, which compares our measure of the U.S. level with those of each of the other G-7 countries. The reader should be cautioned that because of differences in the treatment of computer prices across countries, comparisons of relative productivity levels going back in time become less accurate the further one gets from the base period (1991)). The computer price effect could bias downward our estimates of the levels of

\footnotetext{
${ }^{23}$ Data on hours at the subsector level are available from national accounts the United
} States and Canada. In both countries, hours per employee appear to be relatively stable across subsectors. Nevertheless, hours are preferable over employment in cross-country comparisons of productivity, because of significant cross-country differences in hours per employee in total manufacturing (with the Japanese ratio far exceeding the German ratio for example). Any mismeasurement of hours at the subsector level does not affect our estimation of unit labor costs below, since: hours cancel out of the numerator and the denominator of unit labor costs.

${ }^{24}$ These extrapolations and the data underlying Charts 1-3 below, which show movements over time in unit labor costs and their components, are based on indexes constructed by the BLS and the IMFi. 
European and Japanese productivity in total manufacturing (and especially in the machinery and equipment subsector) in 1985 by as much as several percentage points. ${ }^{25}$

These data indicate that while there has been a significant convergence of productivity levels over time, the United States still had the highest level of total manufacturing productivity in 1990. Somewhat surprisingly, France had overtaken Germany and Canada by 1990 to achieve the second highest level of overall manufacturing productivity among the G-7 countries, while Japan and the United Kingdom had the lowest level of productivity throughout the period. These results for total manufacturing mask a wide dispersion of relative productivity levels among manufacturing subsectors across countries. The United States had the most productive textile and apparel, machinery and equipment, and "other manufactures" subsectors, and it was near the top in food. But both Japan and France were clearly ahead in chemicals and basic metals. ${ }^{26}$ Japan's overall productivity level is held back by very low productivity in the food subsector (consistent with the findings of McKinsey (1993)) and the textile subsector.

${ }^{25}$ Wyckoff (1993) examines how the methods used by various countries to calculate computer price deflators affects comparisons of labor productivity. He finds that the use of hedonic versus matched-model methods can lead to substantial differences in estimates of productivity growth, with the difference increasing at each level of disaggregation. S ubstituting the U.S. hedonic computer price index for Germany's non-hedonic index, for example, raised the annual growth rate of Germany's overall manufacturing real output and labor product vity by 20 percent. The same substitution raised the rate of growth of output and productivity in non-electrical machinery in Germany and several other countries by a factor of two or: three. Of the G-7 countries, only the United States and Canada use hedonic price indexes for computers. This factor would not have caused a further bias in our comparisons prior to 1985 , since the United States did not adopt the hedonic index for computers until 1987.

${ }^{26}$ The Japanese data for the chemical subsector are not be fully comparable with the other countries because the Japanese national accounts do not include plastics and rubber products in the chemicals subsector. The Japanese textile subsector also differed from those of other countries in that apparel is included not there but with "other manufactures" instead. 
To provide a clearer picture of the dispersion of productivity across subsectors, Table 12 shows the same data as Table 10, with each country's total manufacturing productivity indexed to 100 . The textile industry has by far the lowest level of productivity in every G-7 country. Chemicals are highest in most cases, except in Italy and the United Kingdom, where the food subsector is most productive. In fact, outside Japan, the food subsector is generally significantly more productive than the overall manufacturing sector. Because of its very low productivity in food and extiles and its very high productivity in chemicals and basic metals, Japan shows the widest dispersion across subsectors.

The bottom two panels of Table 11 present roughly comparable data on productivity from the ICOP project for most of the countries we consider and the ratio of our estimates to the ICOP estimates. These comparisons indicate that our estimate of overall manufacturing productivity in Japan in 1990 is 15 percent less than the ICOP estimate (assuming the estimates for U.S. levels are identical). This difference is in the same direction, but smaller in magnitude, than the 4.0 percent difference between the OPR and the UVR would have predicted. Either the ICOP's estimate of the level of U.S. productivity is significantly below ours or other differences (e.g., distinctions between census and national accounts data) are offsetting the differences in output price ratios. In any event, the two sets of estimates diverge much more dramatically at the subsestor level. Our estimates of productivity in the textile and apparel sector in Japan and Europe, for example, appear to be substantially below the ICOP estimates, reflecting our much higher output price ratios. ${ }^{27}$

${ }^{27}$ In some cases our estimates are only very roughly comparable with the ICOP estimates because cf differences in industry definitions. One key difference is that the ICOP definitions group the fabricated metals and primary metals sectors together while our ISDB-based data 


\section{Compensation}

How productivity translates into unit labor cost levels depends, of course, on the level of labor compensation. Our comparison of compensation levels across countries is based on total wage and nonwage compensation, including health and retirement benefits, leave (including vacations and holidays), and employer expenditures for other legally required programs. These compensation data, too, were taken from OECD national accounts data and are defined on a consistent basis with the value added data.

Table 13 shows compensation per hour for the G-7 countries translated to U.S. dollars at current nominal exchange rates; Table 14 shows the same data indexed to U.S. levels set at 100; and Table 15 the same data indexed to each country's compensation rates for total manufacturing set at 100. Movements over time in comparative compensation rates for total manufaciuring can be seen more clearly in Chart 2, which shows each country's compensation per hour in dollars and in local currency, along with the U.S. level in dollars. These data indicate that exchange rate movements have had a dominant influence on the relative levels of compensation. Whereas U.S. compensation per hour was substantially above that in the other countries in all manufacturing subsectors during 1985, by 1990 it had fallen well below foreign levels in several cases (see especially Table 14) largely as a result of the sharp depreciation of the dollar from its peak level in early 1985. This shift is perhaps most visible in Chart 2 in the cases of Japan and Germany, where the sharp appreciation of the yen and mark against the dollar in recent years has pushed Japanese and German labor compensation measured in U.S. dollars up much faster than U.S.

group fabricated metals with machinery and equipment. As noted in the preceding footnote, there are also important definitional differences with respect to the textile and chemical industries in Japan. 
compensation in recent years. Japanese compensation rates are now above and German rates well above the U.S. level.

The dispersion of compensation rates across sectors is widest in Japan and the United States and narrowest in the continental European countries. (See table 15.) The relatively narrow dispersion in Europe reflects in large part the much greater significance of mandated government programs and employment protection legislation in those countries. In 1990, the ratio of nonwage or "additional" compensation (much of which is government mandated in Europe) to hourly earnings received by manufacturing production workers was more than 75 percent in Italy, France, and Germany, compared with only 18 percent in Japan. The United States and the United Kingdom were in the middle, at 38 percent and 34 percent respectively. Moreover, in the continental European countries union contracts, by law, are extended to non-union workers. Gittleman and Wolff (1993) have found that the degree of cross-sector wage dispersion within countries is negatively correlated with the degree of unionization within countries. As indicated in the bottom two panels of Table 14, our estimates of compensation rates in Japan and Germany (relative to the U.S. levels) are fairly similar to those calculated by the ICOP project. $\underline{\text { Unit labor costs }}$

Our estimates of unit labor costs are shown in Tables 16-18 and Chart 3. The combination of a relatively high level of productivity and moderate level of compensation resulted in the United States having the lowest level of unit labor costs for total manufacturing among the G-7 countries in 1990. The strong influence of movements in nominal exchange rates on relative unit labor cost le:vels can be seen in the shift between 1985 and 1990. In 1985, when the dollar was at a peak level, U.S. unit labor costs for total manufacturing were uniformly higher than those in the 
other G-7 countries. Over much of the period shown in Chart 3, foreign unit labor costs tended to fluctuate around the U.S. level; during the 1970s and 1980s, these pictures seem fully ccnsistent with findings of mean reversion towards purchasing power parity.

When the estimates are extrapolated to 1995, however, differences vis a vis Japan and Germany appear to be outside the range of differences recorded during the 1970s and 1980s. At average nominal exchange rates prevailing during the first eight months of 1995, U.S. unit labor costs were as much as 45 to 50 percent below those in Germany and Japan (see Table $19^{\prime}$ ). ${ }^{28}$ Most of the widening of the gap between U.S. unit labor costs on the one hand and German and Japanese labor costs on the other between 1990 and 1995 can be attributed to movements in nominal exchange rates. ${ }^{29}$ Unit labor costs in France and the United Kingdom were estimated to be noticeably above the U.S. level in 1995, although the gap was a good deal less than in the case of Japan and Germany. Unit labor costs in Italy and Canada were roughly in line with the U.S. level.

These outcomes for total manufacturing did not hold for all subsectors, although the subsectoral comparisons (in Tables 16-18) are somewhat more tentative. Productivity levels in Japan and France in the chemicals and basic metals subsectors appeared to be high enough relative to the U.S. levels to hold their unit labor cost below the U.S. level in 1990. The same was true for

${ }^{28}$ The extrapolations were based in part on BLS and IMF manufacturing unit-labor cost indexes and their components. The observations for 1995 are based on the latest quarterly observations available for productivity and local-currency compensation (generally the first quarter of 1995, but in some cases the fourth quarter of 1994) and averages of nominal dollar exchange rates for the first nine months of 1995.

${ }^{29}$ Between 1990 and early 1995 , manufacturing unit labor costs measured in loca: currencies rose only about 4 percent more in Japan and Germany than in the United States. 
machinery and equipment in Japan and Canada. At the other end of the spectrum, very low levels of productivity in the Japanese food and textile subsectors pushed unit labor costs to more than double the U.S. levels. The levels of unit labor costs in the European textiles and apparel and wood, paper, and nonmetalic metal products subsectors also were extremely high, reflecting the combination of relatively high compensation rates (partly due to government mandated programs) and low productivity. In Europe and the United States, unlike Japan, food and beverages appears to be a relatively high-productivity, low-unit labor cost subsector. In Germany and Japan, the results for total manufacturing reflect those for the machinery and an equipment subsector, which accounts fcr more than half manufacturing output in those countries--a substantially greater share than in the other major industrial countries. Notwithstanding the strong international trade performance that both Germany and Japan have had in machinery, German unit labor costs in that subsector were as much as 40 percent above the U.S. level in 1990 by our estimates, and by 1995 , both German and Japanese unit labor costs would have been substantially above the U.S. level.

Table 19 compares our estimates of unit labor costs for total manufacturing (relative to a U.S. level of 100) with the ICOP or van Ark-Pilat estimates (reported by van Ark (1995)), as well as with those reported in studies by Hooper and Larin (1989) and Turner and Van't dack (1993), both of wh ch employed unadjusted weighted averages of EPPPs on goods, and by Golub (1994), which used the PPP for total GDP. Our estimates for 1990 tend to be somewhat higher than the others in the case of Japan and Germany, but below the estimates reported by Truner and Van't dack for the other countries. For Japan, the van Ark-Pilat estimate is noticeably below the other studies, and for Germany, the Golub estimate is noticeably below the others. In the earlier years, Hooper-Larin appears to be an outlier on the high side for Germany. 
The table also shows our own estimates and the van Ark-Pilat estimates extrapolated to 1995 as described earlier. At average nominal exchange rates for January-September 1995, these estimates show U.S. unit labor costs to be roughly 40 percent below those in both Japan and Germany, compared with our estimate of a 45-50 percent differential. The van Ark-Pilat estimate for France is lower than ours as well, but that for the United Kingdom is very close to ours.

\section{Conclusions.}

Attempts to make international comparisons of levels of unit labor costs have had to contend with significant deficiencies in the data, particularly with respect to the derivation of output price ratios needed to compare labor productivity across countries. Unit value ratios (UVRs) are imperfect measures of relative manufacturing output prices, partly because they suffer from incomplete coverage of finished goods and especially more sophisticated products. Expenditure purchasing power parities (EPPPs) suffer from inadequate coverage of intermediate goods as well as from a variety of factors that cause expenditure PPPs to differ conceptually from output price ratios, including distribution margins, net indirect taxes, and import and exfort prices. Our empirical analysis has focused largely on these latter deficiencies in the EPFP approach. We find that for total manufacturing at least, these deficiencies are less severe, than might have been expected. Distribution margins do make a difference, but in most cases it is not large. Moreover, contrary to widely held perceptions, recent studies have suggested that distribution margins are actually wider in the United States than in other G-7 countries, so that U.S. output prices are even lower relative to those abroad than the EPPPs suggest. The effects of differences in net indirect tax rates appear to be still less important. Our adjustment for the influence of import and export prices had little effect on the outcome, although the adjustment 
was crude and incomplete at best. We also have taken initial steps to improve the coverage of intermediate goods prices by employing UVR-based estimates for the basic metals subsector.

Our results indicate that in 1990, among the G-7 countries, the United States had the lowest level of output prices, the highest level of labor productivity, and the lowest level of unit labor costs for total manufacturing. Extrapolated to 1995 (based on exchange rate data for January thrcugh September of that year), our estimates suggest that U.S. unit labor costs in manufacturing were as much as 45 to 50 percent below those in Germany and Japan, although differences in the machinery and transportation equipment subsector were somewhat smaller and differences 'with other major industrial countries for total manufacturing were considerably smaller. Our estimates differ somewhat from those of other studies. In particular, compared with the results of the ICOP project (based wholly on UVRs), our estimates show a greater difference between U.S. and foreign unit labor costs, especially vis a vis Japan. Nevertheless, both approaches agree that at average nominal exchange rates prevailing during 1995, U.S. manufacturing unit labor costs were well below those in Japan and Germany.

We also considered relative price and productivity levels for various subsectors of manufacturing, though in this case the data and our adjustments are a good deal less precise than for total manufacturing. These disaggregated data seem to suggest that the relatively high level of unit labor costs in the other (non-U.S.) G-7 countries reflects extremely low levels of productivity in the Japanese food and textile subsectors, and relatively high rates of labor compensation in Europe in subsectors (such as textiles and apparel and wood, paper, and nonmetalic metal products) where productivity is relatively low.

While our findings may answer some questions, they raise others--some substantive and 
some methodological. Perhaps the key substantive finding is that of the very large gap that now prevails between U.S. manufacturing unit labor costs on the one hand and German and especially Japanese unit labor costs on the other. Given the tendency for purchasing power parity to be mean-reverting, how would such unit labor cost gaps be likely to close over time--throuigh adjustment of nominal exchange rates or adjustment of domestic prices, wages, or productivity? To what extent do recent downward pressures on wages and prices in Japan reflect such longerterm trend effects? How are these cost differentials reconciled with the persistence of large external deficits in the United States and large external surpluses in Japan--for example, does the existence of such cost differentials indicate the potential for adjustment of these externa] imbalances in the longer term?

The more central focus of this paper has been on methodological issues. We have made some advancements in the EPPP approach to measuring unit labor cost levels, but we also leave ample room for further work in this area. More could be done to refine estimates of distribution margins, especially at the level of manufacturing subsectors. Our adjustment for trade prices is at best only a very crude first attempt. Finally, significant further improvements in the estimation of comparative unit labor cost levels might be made by taking greater advantage of complimentary strengths of the EPPP and UVR approaches. The former approach provides better coverage of finished goods and the latter much better coverage of intermediate goods. We have taken only a preliminary step in this direction, and there is scope for a more comprehensive effort to combine the two approaches. 


\section{REFERENCES}

van Ark, Bart, "Comparative Productivity in British and American Manufacturing," National Institute Economic Review, November, 1992.

, "The ICOP Approach - Its Implications and Applicability," Explaining Economic Growth: Essalys in Honour of Angus Maddison, Elsevier Science Publishers, the Netherlands, 1993. , "Productivity and Competitiveness in Manufacturing: A Comparison of Europe, Japan and the Inited States," International Productivity Differences, Measurement and Explanations, Nor:h Holland, forthcoming, 1995. , and Remco D.J Kouwenhoven, "Productivity in French Manufacturing: An International Comparative Perspective," Institute of Economic Research, University of Groningen, Research Memorandum 571 (GD-10), June 1994.

Betancourt, Roger R., "An Analysis of the U.S. Distribution System," OECD Working Papers, no. 135. Paris, 1993.

Boucher Brəuer, Janice, "An Assessment of the Evidence on Purchasing Power Parity," in John Williamson, ed., Estimating Equilibrium Exchange Rates, Washington: Institute for International Economics, 1994, pp. 245-277.

Davis, Steven J., "Cross-Country Patterns of Change in Relative Wages," National Bureau of Economic Research, Inc., Working Paper, no. 4085, June 1992

Dawson, John A., "The Distribution Sector in the United Kingdom," OECD Working Papers, no. 140. Paris, 1993.

Dollar, David, and Edward N. Wolff, "Convergence of Industry Labor Productivity Among Advanced Economies, 1963-1982," The Review of Economics and Statistics, no. 4, November 1988, pp. 549-558.

Edison, Hali, "Purchasing Power Parity in the Long Run: A Test of the Dollar/Pound Exchange Rate: (1890-78)," The Journal of Money, Credit, and Banking, 1987, pp. 376-87.

Frankel, Jeffrey, "International Capital Mobility and Crowding-out in the U.S. Economy: Imperfect Integration of Financial Markets or of Goods Markets?," How Open is the U.S. Economy, Ruth Hafer, ed., Lexington, Mass: Lexington, 1986, pp. 33-74.

Froot, Kenrieth, and Kenneth Rogoff, "Perspectives on PPP and Long-Run Real Exchange Rates," Handbook of International Economics, G.M. Grossman and K. Rogoff eds. 1995.

Gault, Nigel, "The Competitiveness of U.S. Manufacturing Industry: International Comparisons of Labor, Energy, and Capital Costs," Data Resources, Inc., 1985.

Gittleman, Maury, and Edward N. Wolff, "International Comparisons of Inter-Industry Wage Differentials," Journal of the International Association for Research in Income and Wealth, no. 3, September 1993, pp. 295-312.

Golub, Stephen S., "Comparative Advantage, Exchange Rates, and G-7 Sectoral Trade Balances," IMFi Working Paper 94/5, January 1994.

Hooper, Peter, and Kathryn A. Larin, "International Comparisons of Labor Costs in Marufacturing," Review of Income and Wealth, vol. 35, December 1989, pp. 161-175.

Ito, Takatoshi, and Masayoshi Maruyama, "Is the Japanese Distribution System Really Inefficient," in P. Krugman ed., Trade with Japan, The University of Chicago Press, 1991.

Jorgenson, Dale W., and Masahiro Kuroda, "Productivity and International Competitiveness in 
Japan and the United States, 1960-1985," Economic Studies Quarterly 43, December 1992, pp. 313-25. , and Mieko Nishimizu, "Japan-US Industry-level Comparison, 1960-1979," Journal of the Japanese and International Economies 1, March 1987, pp. 1-30.

Kravis, Irving B., Zoltan Kenessey, Alan Heston and Robert Summers, "A System of International Comparisons of Gross Product and Purchasing Power," United Nations Internaticinal Comparison Project: Phase One, Johns Hopkins University Press, Baltimore, 1975. , Alan Heston, and Robert Summers, "World Product and Income: International Comparisons of Real Gross Product," United Nations International Comparison Project: Phase Three, Johns Hopkins University Press, Baltimore, 1982.

and Robert E. Lipsey, "The International Comparison Program: Current Status and Problems," in P. Hooper and J.D. Richardson, eds., International Economic Traniactions: Issues in Measurement and Empirical Research, University of Chicago Press, Chicago, 1991.

Lachner, Josef, Uwe Chr Tager, and Gunter Weitzel, "The German Distribution System," OECD Working Papers, no. 137, Paris, 1993.

Lawrence, Robert Z., "Issues in Measurement and International Comparison of Output Growth in Manufacturing," in P. Hooper and J.D. Richardson, eds., International Economic Transactions: Issues in Measurement and Empirical Research, University of Chicago Press, Chicago, 1991.

Lichtenberg, Frank R., and Zvi Griliches, "Errors of Measurement in Output Deflators," Journal of Business and Economic Statistics 7, January 1989, pp. 1-9.

Maddison, Angus, and Bart van Ark, "The International Comparison of Real Product and Productivity," Institute of Economic Research, University of Groningen, Research Memorandum 567 (GD-6), April 1994.

Maruyama, Masayoshi, "A Study of the Distribution System in Japan," OECD Working F'apers, no. 136, Paris, 1993.

McKinsey \& Company, Inc., Manufacturing Productivity, Washington, D.C., October 1993.

Messerlin, Patrick A., "The French Distribution Industry and the Openness of the French Economy," OECD Working Papers, no. 138, Paris, 1993.

Neef, Arthur, Christopher Kask, and Christopher Sparks, "International Comparisons of Manufacturing Unit Labor Costs," Monthly Labor Review, December 1993.

Nishimura, Kiyohiko, "The distribution system of Japan and the United States: a comparative study from the viewpoint of final-goods buyers," Japan and the World Economy, vol. 5, 1993, pp. 265-288.

O' Mahony, Mary, "Productivity Levels in British and German Manufacturing Industry," National Institute Economic Review, February 1992, pp. 46-63.

OECD Department of Economics and Statistics, "Purchasing Power Parities and Real Expenditures, 1985," Paris, 1987.

OECD Statistics Directorate, "Purchasing Power Parities and Real Expenditures, 1990," vol. 1, Paris, 1992.

OECD Statistics Directorate, "Purchasing Power Parities and Real Expenditures, 1990," vol. 2, Paris, 1993. 
OECD Statistics Directorate, "National Accounts, 1980-1992," vol. 2, Paris 1994.

OECD Working Paper, "An International Sectoral Database for Thirteen Countries," no. 57, 1988, p. A-1.

OECD, "The: International Sectoral Database," Paris, mimeo, April 1993.

Paige, D. ani G. Bombach, A Comparison of National Output and Productivity of the UK and the US, OEEC, Paris, 1959.

Parker, Robert P., "Gross Product by Industry, 1977-90," Survey of Current Business, May, 1993, pp. 33-54.

Pellegrini, Luca, and Angelo M. Cardani, "The Italian Distribution System," OECD Working Papers, no. 139, Paris, 1993.

Pilat, Dirk, cnd Bart van Ark, "Competitiveness in Manufacturing: A Comparison of Germany, Japan and the United States," BNL Quarterly Review, no. 189, June 1994, pp.167-186. , "Procluctivity Levels in Germany, Japan, and the United States: Differences and Causes", Brockings Papers: Microeconomics 2, 1993.

Prais, S.J., F'roductivity and Industrial Structure: A Statistical Study of Manufacturing Industry in Britcin, Germany, and the United States, Cambridge University Press, New York, 1981.

Roy, A.D., "Labour Productivity in 1980: An International Comparison," National Institute Ecoromic Review, no. 101, August 1982, pp. 26-37.

Roy, D.J., "International Comparisons of Real Value Added, Productivity and Energy Intensity in 1980," Economic Trends, no. 404, June 1987, pp. 87-98.

zu Slochterr, Meyer F.J.M., and J.L. Meyer zu Schlochtern, "An International Sectoral Data Base for Fourteen OECD Countries," OECD Economics Working Papers, no. 145, Paris 1994.

Smith, A.D., D.M.W.N. Hitchens, and S.W. Davies, International Industrial Productivity: A Comparison of Britain, America, and Germany, Cambridge University Press, Cambridge, $198 \%$.

Stoneman, Paul, and Nathan Francis, "Double Deflation and the Measurement of Output and Productivity in UK Manufacturing 1979-1989," presented at a meeting of the ESRC Industrial Economics Study Group at the London Business School in November 1992, revised December 1992.

Stern, Robe t M., "British and American Productivity and Comparative Costs in International Trace," Oxford Economic Papers, October, 1962.

Szirmai, Adam, and Dirk Pilat, "Comparisons of Purchasing Power, Real Output and Labour Procuctivity in Manufacturing in Japan, South Korea and the U.S.A., 1975-85," Review of Income and Wealth, no. 1, March 1990.

Turner, Philip, and Jozef Van't dack, "Measuring International Price and Cost Competitiveness," BIS Economic Papers, no. 39, Bank for International Settlements, Basle, November 1993.

U.S. Department of Commerce, Survey of Current Business, "Benchmark Input-Output Accounts for the U.S. Economy, 1987," vol 74, no. 4, April 1994.

U.S. Department of Commerce, Survey of Current Business, "Benchmark Input-Output Accounts for the U.S. Economy, 1987," vol 74, no. 4, April 1994.

Wie, Shang-Jin and David C. Parsley, "Purchgasing PowerDis-Parity During the Floating Rate Period: Exchange Rate Volatility, Trade Barriers and Other Culprits," Kennedy School, Harvard University, mimeo, April, 1994. 
World Bank International Economics Department,"Purchasing Power of Currencies, Comparing National Incomes Using ICP Data, Technical Note and Sample Tables with *Stars* Diskettes," World Bank, 1993.

Wyckoff, Andrew W., "The Impact of Computer Prices on International Comparisons of Laboul Productivity," MIT/NSF/OECD Conference on the Productivity Impacts of Information Technology Investments, Charleston, North Carolina, November 11-13, 1993. 
Table 1

1990 ICP Expenditure PPPs, Expenditures and Expenditure Shares

\begin{tabular}{|c|c|c|c|c|c|c|c|c|}
\hline \multirow[b]{2}{*}{ Expenditure Category } & \multicolumn{6}{|c|}{ Expenditure PPPs (units of own currency per dollar) } & \multirow{2}{*}{\multicolumn{2}{|c|}{$\begin{array}{c}\text { G-7 Expenditures } \\
\text { Bil. } \$ \% \text { share }\end{array}$}} \\
\hline & Japan & Germany & France & Italy & UK & Canada & & \\
\hline \multicolumn{9}{|l|}{ Food Beverages and Tobacco } \\
\hline Rice & 349 & 2.44 & 6.11 & 1582 & 0.85 & 1.27 & 13.3 & 1.2 \\
\hline Flour, other cereals & 290 & 1.59 & 7.27 & 1658 & 0.52 & 1.53 & 5.0 & 0.4 \\
\hline Bread & 246 & 1.64 & 6.07 & 958 & 0.39 & 1.15 & 55.4 & 4.9 \\
\hline Bakery products, biscuits, cakes, etc. & 226 & 2.09 & 7.06 & 1853 & 0.52 & 1.61 & 38.0 & 3.3 \\
\hline Noodles, macaron $\mathrm{i}$, spaghetti, etc. & 328 & 1.87 & 5.62 & 1469 & 0.52 & 1.28 & 12.0 & 1.1 \\
\hline Cereal preparations & 260 & 1.70 & 6.11 & 2111 & 0.56 & 1.32 & 32.1 & 2.8 \\
\hline Beef and veal & 549 & 2.48 & 7.73 & 1638 & 0.68 & 1.53 & 64.0 & 5.6 \\
\hline Pork & 262 & 1.65 & 6.02 & 1442 & 0.52 & 1.13 & 24.1 & 2.1 \\
\hline Lamb. goat \& multon & 296 & 2.56 & 8.00 & 1530 & 0.53 & 1.02 & 8.7 & 0.8 \\
\hline Poultry & 347 & 3.15 & 12.13 & 2538 & 0.96 & 1.90 & 20.7 & 1.8 \\
\hline Dried or processed meat, etc. & 365 & 2.94 & 10.39 & 2484 & 0.67 & 1.58 & 72.0 & 6.3 \\
\hline Fish fresh/frozen & 223 & 2.03 & 6.94 & 2013 & 0.57 & 1.20 & 29.8 & 2.6 \\
\hline Processed fish/seafood, canned, etc. & 238 & 1.71 & 6.87 & 1607 & 0.47 & 1.29 & 13.0 & 1.1 \\
\hline Smoked or preserved fish \& seafoods & 230 & 2.05 & 7.23 & 1891 & 0.68 & 1.25 & 11.0 & 1.0 \\
\hline Other seafoods & 133 & 3.44 & 11.25 & 3413 & 0.70 & 1.37 & 10.1 & 0.9 \\
\hline Milk fresh & 315 & 1.61 & 6.88 & 2027 & 0.71 & 1.64 & 44.9 & 4.0 \\
\hline Milk preserved & 237 & 1.85 & 6.08 & 3250 & 0.48 & 1.33 & 6.3 & 0.6 \\
\hline Other milk products & 289 & 1.36 & 6.78 & 2027 & 0.77 & 1.88 & 13.5 & 1.2 \\
\hline Cheese & 246 & 1.98 & 6.44 & 1332 & 0.54 & 1.44 & 34.6 & 3.0 \\
\hline Eggs \& egg prodt cts & 239 & 2.41 & 13.09 & 2536 & 1.20 & 1.55 & 10.7 & 0.9 \\
\hline Butter & 353 & 1.72 & 7.39 & 2052 & 0.61 & 1.34 & 6.6 & 0.6 \\
\hline Margarine, edible oils \& lard & 383 & 1.78 & 6.44 & 1484 & 0.46 & 1.22 & 13.2 & 1.2 \\
\hline Fresh fruits & 254 & 2.48 & 7.42 & 970 & 0.60 & 1.09 & 49.1 & 4.3 \\
\hline Dried, frozen, pre served, juices, etc. & 194 & 1.31 & 6.69 & 1272 & 0.43 & 1.21 & 33.4 & 2.9 \\
\hline Fresh vegetables & 204 & 1.80 & 6.48 & 1080 & 0.76 & 1.02 & 48.1 & 4.2 \\
\hline Dried, frozen, preserved vegetables & 395 & 2.37 & 9.04 & 2366 & 0.83 & 1.45 & 26.0 & 2.3 \\
\hline Tubers, including potatoes & 249 & 1.74 & 6.26 & 1240 & 0.57 & 1.40 & 17.6 & 1.5 \\
\hline Coffee & 249 & 2.51 & 3.60 & 1755 & 0.75 & 1.46 & 26.6 & 2.3 \\
\hline Tea & 429 & 4.04 & 10.27 & 2926 & 0.55 & 0.85 & 6.0 & 0.5 \\
\hline Cocoa & 409 & 2.34 & 10.10 & 1149 & 0.76 & 1.67 & 3.2 & 0.3 \\
\hline Sugar & 240 & 1.70 & 5.73 & 1125 & 0.54 & 1.01 & 8.9 & 0.8 \\
\hline Jam, syrup, honey' \& the like & 243 & 2.09 & 5.06 & 2024 & 0.56 & 0.99 & 6.4 & 0.6 \\
\hline Chocolate, ice cre am, etc. & 308 & 2.05 & 7.40 & 2506 & 0.62 & 1.48 & 68.4 & 6.0 \\
\hline Condiments, spices, salt, etc. & 245 & 2.74 & 9.83 & 2091 & 0.87 & 2.28 & 21.5 & 1.9 \\
\hline Mineral water & 230 & 0.92 & 2.41 & 429 & 0.27 & 1.56 & 12.8 & 1.1 \\
\hline Soft drinks & 309 & 2.18 & 7.15 & 2020 & 0.75 & 1.86 & 36.6 & 3.2 \\
\hline Liquors \& spirits & 274 & 2.08 & 7.30 & 1228 & 0.98 & 1.90 & 26.4 & 2.3 \\
\hline Wine, cider & 204 & 0.89 & 2.83 & 357 & 0.52 & 1.19 & 44.6 & 3.9 \\
\hline Beer & 315 & 1.09 & 5.14 & 1291 & 0.68 & 1.92 & 49.4 & 4.3 \\
\hline Other alcoholic beverages & 347 & 2.56 & 10.44 & 2137 & 1.15 & 2.66 & 10.4 & 0.9 \\
\hline Cigarettes & 132 & 2.52 & 5.75 & 1389 & 0.93 & 2.36 & 96.5 & 8.5 \\
\hline Other tobacco products \& stimulants & 497 & 2.72 & 7.18 & 1625 & 1.05 & 2.72 & 6.4 & 0.6 \\
\hline Total Food Beverages and Tobacco & 281 & 2.07 & 6.97 & 1666 & 0.67 & 1.54 & 1137.2 & 100.0 \\
\hline
\end{tabular}


(Table 1 continued)

Textile, apparel, and leather products

\begin{tabular}{|c|c|c|c|c|c|c|c|c|}
\hline \\
\hline Men's clothing & 210 & 2.70 & 10.16 & 2116 & 0.64 & 1.51 & 131.1 & 25.0 \\
\hline Women's clothing & 226 & 2.62 & 9.85 & 2000 & 0.64 & 1.49 & 150.2 & 28.7 \\
\hline Children's clothing & 405 & 4.35 & 18.53 & 3599 & 1.06 & 1.49 & 54.4 & 10.4 \\
\hline Clothing accessories & 229 & 3.70 & 14.55 & 2808 & 1.05 & 1.35 & 33.4 & 6.4 \\
\hline Clothing, rental and repair & 140 & 2.14 & 9.61 & 1833 & 0.97 & 1.21 & 10.6 & 2.0 \\
\hline Footwear, men's & 173 & 2.33 & 9.65 & 1774 & 0.54 & 1.56 & 21.4 & 4.1 \\
\hline Footwear, women's & 232 & 3.09 & 11.56 & 2300 & 0.81 & 2.24 & 26.0 & 5.0 \\
\hline Footwear, children's, infants' & 98 & 2.47 & 8.94 & 1807 & 0.51 & 1.21 & 21.1 & 4.0 \\
\hline Household textiles, etc. & 82 & 1.53 & 7.15 & 1047 & 0.44 & 1.48 & 53.4 & 10.2 \\
\hline Floor coverings & 222 & 1.52 & 6.27 & 1705 & 0.48 & 1.53 & 22.5 & 4.3 \\
\hline Total Textile, apparel, and leather products & 217 & 2.73 & 10.73 & 2131 & 0.69 & 1.51 & 524.1 & 100.0 \\
\hline \multicolumn{9}{|l|}{ Chemical, petroleum, rubber, and plastic products } \\
\hline Gas & 481 & 3.46 & 13.49 & 2715 & 1.15 & 1.23 & 45.2 & 5.1 \\
\hline Liquid heating fuels & 210 & 1.80 & 7.39 & 1965 & 0.73 & 1.08 & 46.3 & 5.2 \\
\hline Automotive Fuel \& lubricant & 394 & 4.51 & 16.04 & 4279 & 1.51 & 1.88 & 154.2 & 17.4 \\
\hline Other fuels & 1062 & 4.91 & 20.61 & 3467 & 1.50 & 1.88 & 3.6 & 0.4 \\
\hline Tires, tubes, accessories & 217 & 1.68 & 7.63 & 1744 & 0.88 & 1.46 & 71.7 & 8.1 \\
\hline Cleaning maintenance supplies & 205 & 2.68 & 7.61 & 1714 & 0.72 & 1.43 & 35.5 & 4.0 \\
\hline Drugs \& medical preparations & 78 & 1.60 & 2.87 & 713 & 0.35 & 1.10 & 419.4 & 47.4 \\
\hline Medical supplies & 153 & 2.19 & 4.75 & 777 & 0.49 & 1.26 & 34.8 & 3.9 \\
\hline Toilet articles (all kinds) & 315 & 2.58 & 9.97 & 2036 & 0.89 & 1.66 & 74.7 & 8.4 \\
\hline Total Chemical, petroleum, rubber, and plastic products & 204 & 2.38 & 7.26 & 1751 & 0.73 & 1.34 & 885.4 & 100.0 \\
\hline \multicolumn{9}{|l|}{ Machinery, equipment, and fabricated metal products } \\
\hline Cutlery and flatware & 420 & 3.13 & 7.87 & 1944 & 0.90 & 1.94 & 2.8 & 0.2 \\
\hline Domestic utensils without motor & 228 & 1.93 & 7.13 & 1331 & 0.75 & 1.55 & 21.0 & 1.3 \\
\hline Refrigerators, freezers, etc. & 314 & 2.19 & 10.31 & 1502 & 0.71 & 1.77 & 10.6 & 0.7 \\
\hline Washing \& cleaning appliances & 121 & 1.46 & 5.78 & 1087 & 0.38 & 1.49 & 24.1 & 1.5 \\
\hline Cooking \& other food warming appliances & 217 & 2.27 & 9.81 & 2003 & 0.92 & 1.49 & 15.0 & 0.9 \\
\hline Sewing machines, fans, toasters, etc. & 332 & 3.06 & 12.26 & 2743 & 0.95 & 1.41 & 10.4 & 0.7 \\
\hline Room climate control equipment & 403 & 1.35 & 5.64 & 1146 & 0.39 & 1.22 & 11.4 & 0.7 \\
\hline Garden appliances & 287 & 2.77 & 10.51 & 3308 & 1.68 & 1.97 & 1.7 & 0.1 \\
\hline Light-bulb, cable, switches, etc. & 128 & 2.16 & 7.71 & 1180 & 0.97 & 1.07 & 11.6 & 0.7 \\
\hline Therapeutic appliances \& equipment & 183 & 1.73 & 5.74 & 1692 & 0.57 & 1.01 & 66.0 & 4.1 \\
\hline Radios, televisions, phonographs & 144 & 2.63 & 10.11 & 2149 & 0.68 & 1.69 & 60.6 & 3.8 \\
\hline Musical instruments, boats, etc. & 179 & 1.76 & 7.58 & 1321 & 0.40 & 1.03 & 22.6 & 1.4 \\
\hline Camera, VCR, \& other optical equip. & 164 & 2.12 & 8.97 & 1670 & 0.63 & 1.51 & 51.2 & 3.2 \\
\hline Engines, turbines & 222 & 2.47 & 9.73 & 1913 & 0.78 & 1.79 & 19.2 & 1.2 \\
\hline Agricultural machinery & 179 & 1.61 & 5.98 & 1247 & 0.66 & 0.97 & 54.1 & 3.4 \\
\hline Office machinery $\&$ equipment & 993 & 10.49 & 43.79 & 10211 & 3.89 & 6.80 & 40.6 & 2.6 \\
\hline Metal \& woodworking machinery & 304 & 3.00 & 10.26 & 2489 & 1.05 & 1.60 & 80.5 & 5.1 \\
\hline Tool, finished metal & 206 & 3.31 & 9.63 & 2297 & 0.57 & 1.15 & 33.6 & 2.1 \\
\hline Construction, mining \& oil field & 139 & 1.95 & 6.89 & 1758 & 0.62 & 1.10 & 80.9 & 5.1 \\
\hline Textile \& leather working machinery & 127 & 2.40 & 11.90 & 2094 & 0.87 & 1.17 & 11.0 & 0.7 \\
\hline Other machinery equipment & 206 & 2.13 & 6.06 & 1403 & 0.67 & 1.46 & 86.4 & 5.4 \\
\hline
\end{tabular}


(Table 1 continued)

\begin{tabular}{|c|c|c|c|c|c|c|c|c|}
\hline Precision, optical instruments & 189 & 1.59 & 6.36 & 1602 & 0.68 & 0.84 & 61.3 & 3.9 \\
\hline Electrical equipment, including lights & 222 & 2.95 & 10.62 & 2311 & 1.00 & 1.24 & 71.9 & 4.5 \\
\hline Other electrical equipment & 60 & 1.01 & 5.30 & 1182 & 0.44 & 0.66 & 46.4 & 2.9 \\
\hline Telecom. \& measuring instruments & 115 & 2.48 & 7.18 & 1468 & 0.52 & 1.22 & 113.5 & 7.1 \\
\hline Passenger cars (consumption) & 145 & 1.95 & 7.17 & 1548 & 0.77 & 1.41 & 330.6 & 20.8 \\
\hline Other personal transport & 150 & 1.96 & 7.02 & 1587 & 0.65 & 0.86 & 20.6 & 1.3 \\
\hline Motor vehicles, engines & 157 & 2.87 & 10.31 & 2263 & 1.00 & 1.53 & 178.2 & 11.2 \\
\hline Railway $v$ shicles & 99 & 1.68 & 5.64 & 1855 & 0.84 & 1.73 & 12.6 & 0.8 \\
\hline Aircraft & 104 & 1.94 & 6.94 & 1812 & 0.95 & 1.54 & 18.0 & 1.1 \\
\hline Ships, boats & 104 & 1.94 & 6.94 & 1812 & 0.95 & 1.54 & 17.3 & 1.1 \\
\hline Other tran;port equipment & 104 & 2.03 & 7.55 & 1718 & 0.99 & 1.44 & 4.7 & 0.3 \\
\hline Total machineıy, equipment, and fabricated metal produ & 190 & 2.42 & 8.84 & 1972 & 0.83 & 1.47 & 1590.3 & 100.0 \\
\hline Total machine $y$, etc. excl. office machinery & 169 & 2.21 & 7.92 & 1756 & 0.75 & 1.33 & 1549.7 & \\
\hline \multicolumn{9}{|l|}{$\begin{array}{l}\text { Other manufastured products } \\
\text { Furniture fixtures }\end{array}$} \\
\hline Furniture, fixtures & 243 & 1.91 & 7.05 & 1500 & 0.59 & 1.40 & 116.2 & 26.8 \\
\hline Books, nervspapers, magazines, etc. & 227 & 2.47 & 5.93 & 1814 & 0.61 & 1.56 & 80.4 & 18.5 \\
\hline Stationery non-educational & 377 & 3.14 & 10.67 & 2267 & 0.78 & 1.84 & 18.3 & 4.2 \\
\hline Glassware \& tableware & 50 & 0.55 & 1.48 & 251 & 0.15 & 0.46 & & 0.0 \\
\hline Jewelry, watches, etc. & 237 & 2.94 & 11.22 & 1720 & 0.91 & 1.76 & 60.6 & 14.0 \\
\hline Other persınal care goods & 169 & 2.11 & 6.25 & 1870 & 0.74 & 1.42 & 38.3 & 8.8 \\
\hline Other non-durable household products & 217 & 2.31 & 9.99 & 2986 & 0.57 & 1.67 & 52.6 & 12.1 \\
\hline Semi \& non-durable recreation goods & 182 & 2.04 & 7.34 & 1729 & 0.51 & 1.79 & 68.0 & 15.7 \\
\hline Total other manufactured products & 225 & 2.30 & 7.91 & 1870 & 0.64 & 1.59 & 434.2 & 100.0 \\
\hline
\end{tabular}

Source: World Bank (1993) and authors' calculations. 
Table 2

1990 Purchasing Power Parities (Units of Local Currency per Dollar)

\begin{tabular}{|c|c|c|c|c|c|c|c|}
\hline & US & Japan & Germany & France & Italy & UK & Canada \\
\hline \multicolumn{8}{|c|}{ Food Beverages and Tobacco } \\
\hline EPPP & 1.00 & 280.70 & 2.07 & 6.97 & 1666.00 & 0.67 & 1.54 \\
\hline EPPPt & 1.00 & 315.57 & 2.18 & 6.94 & 1760.07 & 0.73 & 1.54 \\
\hline EPPP* & 1.00 & 270.25 & 2.00 & 7.89 & 1749.78 & 0.73 & 1.70 \\
\hline OPR & 1.00 & 285.07 & 1.96 & 7.67 & 1787.67 & 0.73 & 1.67 \\
\hline UVR & & 202.71 & 1.88 & 6.91 & & 0.74 & \\
\hline \multicolumn{8}{|c|}{ Textile, apparel, and leather products } \\
\hline EPPP & 1.00 & 217.35 & 2.73 & 10.73 & 2131.04 & 0.69 & 1.51 \\
\hline EPPPt & 1.00 & 244.35 & 2.87 & 10.68 & 2251.37 & 0.75 & 1.51 \\
\hline EPPP* & 1.00 & 227.17 & 2.86 & 10.53 & 2279.20 & 0.75 & 1.50 \\
\hline OPR & 1.00 & 335.48 & 4.71 & 15.94 & 2735.98 & 0.99 & 1.89 \\
\hline UVR & & 186.34 & 2.71 & 8.05 & & 0.77 & \\
\hline \multicolumn{8}{|c|}{ Chemical, petroleum, rubber, and plastic products } \\
\hline EPPP & 1.00 & 203.54 & 2.38 & 7.26 & 1750.55 & 0.73 & 1.34 \\
\hline EPPPt & 1.00 & 228.82 & 2.51 & 7.23 & 1849.39 & 0.79 & 1.34 \\
\hline EPPP* & 1.00 & 205.92 & 2.31 & 6.16 & 2037.49 & 0.75 & 1.39 \\
\hline OPR & 1.00 & 207.86 & 2.25 & 6.18 & 2246.25 & 0.75 & 1.40 \\
\hline UVR & & 159.85 & 2.12 & 6.22 & & 0.54 & \\
\hline \multicolumn{8}{|c|}{ Basic metal industries } \\
\hline UVR & 1.00 & 165.78 & 2.02 & 6.99 & & 0.66 & \\
\hline \multicolumn{8}{|c|}{ Machinery, equipment, and fabricated metal products, } \\
\hline EPPP & 1.00 & 169.38 & 2.21 & 7.92 & 1755.68 & 0.75 & 1.33 \\
\hline EPPPt & 1.00 & 190.42 & 2.33 & 7.88 & 1854.81 & 0.81 & 1.33 \\
\hline EPPP* & 1.00 & 184.33 & 2.36 & 7.95 & 1924.73 & 0.83 & 1.32 \\
\hline OPR & 1.00 & 186.12 & 2.25 & 8.16 & 1917.77 & 0.86 & 1.28 \\
\hline UVR & & 122.78 & 2.14 & 7.41 & & 0.73 & \\
\hline \multicolumn{8}{|c|}{ Other manufactured products } \\
\hline EPPP & 1.00 & 225.46 & 2.30 & 7.91 & 1869.53 & 0.64 & 1.59 \\
\hline EPPPt & 1.00 & 253.47 & 2.42 & 7.87 & 1975.09 & 0.70 & 1.59 \\
\hline EPPP* & 1.00 & 244.39 & 2.42 & 7.80 & 2024.93 & 0.70 & 1.57 \\
\hline OPR & 1.00 & 256.40 & 2.52 & 8.20 & 2016.06 & 0.72 & 1.60 \\
\hline UVR & & 200.10 & 2.22 & 6.99 & & 0.92 & \\
\hline \multicolumn{8}{|c|}{ Total Manufacturing } \\
\hline EPPP & 1.00 & 198.32 & 2.25 & 7.78 & 1794.30 & 0.71 & 1.41 \\
\hline EPPPt & 1.00 & 221.61 & 2.36 & 7.75 & 1888.54 & 0.77 & 1.41 \\
\hline EPPP* & 1.00 & 208.51 & 2.33 & 7.70 & 1957.19 & 0.77 & 1.42 \\
\hline OPR & 1.00 & 217.86 & 2.36 & 8.07 & 2004.76 & 0.79 & 1.43 \\
\hline UVR & 1.00 & 156.87 & 2.14 & 7.10 & & 0.74 & \\
\hline ER & 1.00 & 144.79 & 1.61 & 5.43 & 1195.35 & 0.56 & 1.17 \\
\hline
\end{tabular}

EPPP $=$ Expenditure PPP

EPPPm $=$ Expenditure PPP adjusted for wholesale and retail distribution margins.

EPPP* $=$ EPPPm adjusted for net taxes and subsidies

OPR = Output price ratio (EPPP* adjusted for import and export prices)

UVR $=$ Van Ark-Pilat Unit Value Ratio

$\mathrm{ER}=$ Nominal exchange rate 
Table 3

1990 Dollar Price Levels (U.S. Expenditure Price Level=1.0)

\begin{tabular}{|c|c|c|c|c|c|c|c|c|}
\hline & US & Japan & Germany & France & Italy & UK & Canada & $\begin{array}{l}\text { G-7 Dollar } \\
\text { Price Level* }\end{array}$ \\
\hline \multicolumn{9}{|c|}{ Food Beverages and Tobacco } \\
\hline EP & 1.00 & 1.94 & 1.28 & 1.28 & 1.39 & 1.20 & 1.32 & \multirow{4}{*}{0.72} \\
\hline EPt & 0.63 & 1.37 & 0.85 & 0.80 & 0.93 & 0.82 & 0.83 & \\
\hline EP* & 0.56 & 1.04 & 0.69 & 0.81 & 0.81 & 0.73 & 0.81 & \\
\hline $\mathrm{P}$ & 0.56 & 1.11 & 0.69 & 0.79 & 0.84 & 0.73 & 0.81 & \\
\hline \multicolumn{9}{|c|}{ Textile, apfarel, and leather products } \\
\hline EP & 1.00 & 1.50 & 1.69 & 1.98 & 1.78 & 1.23 & 1.29 & \multirow{4}{*}{0.86} \\
\hline $\mathrm{EPt}$ & 0.63 & 1.06 & 1.12 & 1.24 & 1.19 & 0.84 & 0.81 & \\
\hline EP* & 0.62 & 0.97 & 1.10 & 1.20 & 1.18 & 0.82 & 0.80 & \\
\hline $\mathrm{P}$ & 0.45 & 1.05 & 1.32 & 1.33 & 1.03 & 0.80 & 0.73 & \\
\hline \multicolumn{9}{|c|}{ Chemical, petroleum, rubber, and plastic products } \\
\hline EP & 1.00 & 1.41 & 1.48 & 1.34 & 1.46 & 1.30 & 1.15 & \multirow{4}{*}{0.69} \\
\hline $\mathrm{EPt}$ & 0.63 & 0.99 & 0.98 & 0.84 & 0.97 & 0.89 & 0.72 & \\
\hline EP* & 0.57 & 0.81 & 0.81 & 0.65 & 0.97 & 0.76 & 0.68 & \\
\hline $\mathrm{P}$ & 0.57 & 0.81 & 0.79 & 0.64 & 1.06 & 0.75 & 0.68 & \\
\hline \multicolumn{9}{|c|}{ Basic metal industries } \\
\hline UV & 1.00 & 1.15 & 1.25 & 1.29 & & 1.18 & & \\
\hline \multicolumn{9}{|c|}{ Machinery, equipment, and fabricated metal products, } \\
\hline EP & 1.00 & 1.17 & 1.37 & 1.46 & 1.47 & 1.33 & 1.14 & \multirow{4}{*}{0.76} \\
\hline EPt & 0.63 & 0.83 & 0.91 & 0.91 & 0.98 & 0.91 & 0.72 & \\
\hline EP* & 0.61 & 0.78 & 0.90 & 0.90 & 0.99 & 0.91 & 0.70 & \\
\hline $\mathbf{P}$ & 0.60 & 0.77 & 0.84 & 0.90 & 0.96 & 0.92 & 0.66 & \\
\hline \multicolumn{9}{|c|}{ Other manufactured products } \\
\hline EP & 1.00 & 1.56 & 1.42 & 1.46 & 1.56 & 1.15 & 1.36 & \multirow{4}{*}{0.81} \\
\hline EPt & 0.63 & 1.10 & 0.95 & 0.91 & 1.04 & 0.78 & 0.86 & \\
\hline EP* & 0.61 & 1.04 & 0.92 & 0.88 & 1.04 & 0.77 & 0.83 & \\
\hline $\mathrm{P}$ & 0.59 & 1.05 & 0.92 & 0.90 & 1.00 & 0.76 & 0.82 & \\
\hline \multicolumn{9}{|c|}{ Total Manu facturing } \\
\hline EP & 1.00 & 1.32 & 1.38 & 1.42 & 1.52 & 1.25 & 1.22 & \\
\hline EPt & 0.64 & 0.97 & 0.95 & 0.92 & 1.04 & 0.87 & 0.80 & \\
\hline EP* & 0.62 & 0.89 & 0.90 & 0.87 & 1.03 & 0.83 & 0.77 & \\
\hline$P$ & 0.60 & 0.89 & 0.87 & 0.88 & 1.01 & 0.83 & 0.75 & \\
\hline ER & 1.00 & 145 & 1.61 & 5.43 & 1195 & 0.56 & 1.17 & \\
\hline
\end{tabular}

$\mathrm{PE}=$ Expen diture price level

$\mathrm{PEm}=$ Expenditure price level adjusted for wholesale and retail distribution margins.

$\mathrm{PE}^{*}=\mathrm{PEm}$ adjusted for net taxes and subsidies

$\mathrm{OPR}=$ Output price (PE* adjusted for import and export prices)

UVR $=$ Van Ark-Pilat Unit Value Ratio

$\mathrm{ER}=$ Nomirial exchange rate 
Table 4

1990 Output in Billions of DollarsTranslated at PPP, factor cost

\begin{tabular}{lrrrrrrr} 
& US & Japan & Germany & France & Italy & UK & Canada \\
\hline Food, Beverages, and Tobacco & 85.7 & 31.9 & 30.4 & 23.3 & 17.0 & 31.0 & 9.2 \\
Textiles, apparel, and leather products & 48.4 & 6.4 & 5.8 & 5.2 & 17.1 & 6.2 & 3.1 \\
Chemical, petroleum, rubber, and plastic produ & 149.1 & 53.8 & 46.8 & 29.9 & 17.0 & 21.0 & 10.2 \\
Basic Metals & 35.1 & 58.0 & 27.0 & 10.6 & 6.5 & 6.2 & 5.0 \\
Machinery, equipment, and fabricated metal pr & 379.4 & 285.5 & 156.8 & 67.2 & 55.8 & 53.3 & 27.1 \\
Other manufactured products & 202.3 & 105.5 & 35.8 & 27.8 & 29.3 & 30.7 & 18.6 \\
\hline Total Manufacturing & 900.1 & 541.0 & 302.6 & 163.9 & 142.7 & 148.4 & 73.1
\end{tabular}

1990 G-7 Output and Expenditures

Food, Beverages, and Tobacco

Textiles, apparel, and leather products

Chemical, petroleum, rubber, and plastic products

Basic Metals

Machinery, equipment, and fabricated metal products, Other manufactured products

Total Manufacturing

\begin{tabular}{rrrr}
$\begin{array}{l}\text { Output } \\
\text { (\$billions) }\end{array}$ & \%Share & $\begin{array}{r}\text { Expenditur } \\
\text { (\$billions) }\end{array}$ \\
228 & 10.1 & 1137 & 25.1 \\
92 & 4.1 & 524 & 11.6 \\
328 & 14.4 & 885 & 19.5 \\
148 & 6.5 & & 0.0 \\
1025 & 45.1 & 1550 & 34.2 \\
450 & 19.8 & 434 & 9.6 \\
\hline 2272 & 100.0 & 4531 & 100.0
\end{tabular}

Source: OECD ISDB and National Accounts, ICP PPPs and expenditures and authors' calculations.

Note: Output at market price for France, Germany, Japan, and the United States were adjusted to factor cost using OECD data on net taxes and subsidies. 
Table 5

Manufacturing Wholesale and Retail Distribution Margins

(percent of sales)

\begin{tabular}{lrrrrrrr} 
& US & \multicolumn{2}{c}{ Japan Germany } & France & Italy & UK & Canada \\
\hline Wholesale & 20.1 & 11.2 & 16.8 & 23.1 & 22.4 & 13.4 & 20.1 \\
Retail & 32.3 & 27.1 & 29.0 & 29.7 & 22.9 & 28.8 & 32.3 \\
\hline Total & 58.9 & 41.3 & 50.7 & 59.7 & 50.4 & 46.1 & 58.9
\end{tabular}

Sources:

France: Messerlin (1993) pp 32-33 (data for 1987).

Germany: Lachner et. al, (1993) pp 80, 129 (data for 1987).

Italy: Pellegrini and Cardani (1993), p 34 (data for 1988).

Japan: Maruyama (1993) p 60 (data for 1986).

UK: Dawson (1993) pp 69-70 (data for 1984 and 1988).

US: Betancoult (1993) pp 26, 30 (data for 1987).

(Canadian margins assumed to equal U.S. margins.)

Margins reported by Ito and Maruyama (1993) for year shown.

\begin{tabular}{lrrrrrrr}
\hline & US & Japan Germany & France & Italy & UK & Canada \\
\hline Wholesale & 1986 & 1986 & 1985 & 1985 & 1984 & \\
Retail & 19.4 & 11.2 & 12.6 & 21.8 & 13.4 & \\
\hline Total & 31 & 27.1 & 34.2 & 29.6 & 27.6 & \\
& 56.4 & 41.3 & 51.1 & 57.9 & & 44.7
\end{tabular}


$-50-$

Table 6

Indirect Taxes Net of Subsidies

(percent of value added)

\begin{tabular}{lrrrrrrr} 
& US & Japan & Germany & France & Italy & \multicolumn{2}{r}{ UK Canada } \\
\hline Food Beverages and Tobacco & 13.24 & 32.23 & 23.74 & -0.39 & 13.90 & 12.42 & 2.57 \\
Textile, apparel, and leather products & 1.57 & 9.25 & 2.14 & 3.08 & 0.33 & 1.85 & 2.34 \\
Chemical, petroleum, rubber, and plastic produ & 10.73 & 23.04 & 20.56 & 29.79 & 0.51 & 16.95 & 6.54 \\
Basic metal industries & 4.85 & 5.67 & -0.48 & 3.87 & -5.15 & -0.59 & 4.66 \\
Machinery. equipment. and fabricated metal pr & 2.55 & 5.94 & 1.40 & 1.76 & -1.18 & 0.66 & 2.95 \\
Other manufactured products & 2.38 & 6.18 & 2.59 & 3.25 & -0.14 & 1.90 & 4.05 \\
\hline Total manufactures & 5.05 & 11.04 & 7.40 & 7.42 & 1.02 & 5.2 & 3.77
\end{tabular}

Source: Computed form OECD ISDB.

(U.K. indirect taxes assumed to equal average of France +Germany+Italy.) 
$-51-$

Table 7

Trade Balances in 1990

(percent of value added )

\begin{tabular}{lrrrrrrr} 
& US & Japan & Germany & France & Italy & UK & Canada \\
\hline Food Beverages and Tobacco & 3.9 & -22.1 & -12.1 & 15.4 & -29.8 & -16.5 & 4.0 \\
Textile, apparel, and leather products & -68.7 & -68.6 & -93.6 & -36.9 & 46.6 & -72.4 & -96.4 \\
Chemical, petroleum, rubber, and plastic produ & -2.0 & -3.4 & 19.4 & -1.9 & -33.7 & 8.9 & -10.1 \\
Basic metal industries & -27.7 & -0.5 & 1.9 & -7.9 & -41.2 & -17.5 & 64.9 \\
Machinery, ecuipment, and fabricated metal pr & -9.1 & 44.9 & 43.5 & -2.7 & 11.0 & -10.4 & -57.5 \\
Other manufartured products & -11.6 & -5.1 & -2.6 & -15.4 & 17.7 & -30.1 & 50.2 \\
& & & & & & & \\
Total Manufarturing & -11.1 & 15.4 & 19.6 & -4.8 & 6.1 & -16.3 & -7.1 \\
\hline
\end{tabular}


Table 8

1990 Dollar Price Levels (U.S. Expenditure Price Level=1.0)

\begin{tabular}{|c|c|c|c|c|c|c|c|c|}
\hline & US & Japan & Germany & France & Italy & UK & Canada & G-7 \\
\hline \multicolumn{9}{|c|}{ Food Beverages and Tobacco } \\
\hline EP & 1.78 & 3.45 & 2.28 & 2.28 & 2.48 & 2.13 & 2.35 & \multirow{4}{*}{1.28} \\
\hline EPt & 1.12 & 2.44 & 1.52 & 1.43 & 1.65 & 1.46 & 1.48 & \\
\hline EP & 0.99 & 1.84 & 1.23 & 1.44 & 1.45 & 1.30 & 1.44 & \\
\hline $\mathrm{P}$ & 1.00 & 1.97 & 1.22 & 1.41 & 1.50 & 1.30 & 1.44 & \\
\hline \multicolumn{9}{|c|}{ Textile, apparel, and leather products } \\
\hline EP & 2.21 & 3.32 & 3.74 & 4.38 & 3.95 & 2.72 & 2.87 & \multirow{4}{*}{1.91} \\
\hline EPt & 1.39 & 2.35 & 2.49 & 2.74 & 2.63 & 1.86 & 1.80 & \\
\hline EP & 1.37 & 2.15 & 2.43 & 2.66 & 2.62 & 1.83 & 1.76 & \\
\hline $\mathrm{P}$ & 1.00 & 2.32 & 2.92 & 2.93 & 2.29 & 1.76 & 1.62 & \\
\hline \multicolumn{9}{|c|}{ Chemical, petroleum, rubber, and plastic products } \\
\hline EP & 1.77 & 2.48 & 2.61 & 2.36 & 2.59 & 2.29 & 2.03 & \multirow{4}{*}{1.21} \\
\hline EPt & 1.11 & 1.76 & 1.73 & 1.48 & 1.72 & 1.57 & 1.28 & \\
\hline EP & 1.00 & 1.43 & 1.44 & 1.14 & 1.71 & 1.34 & 1.20 & \\
\hline $\mathrm{P}$ & 1.00 & 1.44 & 1.39 & 1.14 & 1.88 & 1.33 & 1.20 & \\
\hline \multicolumn{9}{|c|}{ Basic metal industries } \\
\hline UV & 0.57 & 0.81 & 0.79 & 0.64 & & 0.75 & & \\
\hline \multicolumn{9}{|c|}{ Machinery, equipment, and fabricated metal products, } \\
\hline EP & 1.67 & 1.95 & 2.29 & 2.43 & 2.45 & 2.22 & 1.90 & \multirow{4}{*}{1.27} \\
\hline EPt & 1.05 & 1.38 & 1.52 & 1.52 & 1.63 & 1.52 & 1.19 & \\
\hline EP & 1.02 & 1.30 & 1.50 & 1.50 & 1.65 & 1.51 & 1.16 & \\
\hline $\mathrm{P}$ & 1.00 & 1.29 & 1.40 & 1.50 & 1.60 & 1.53 & 1.10 & \\
\hline \multicolumn{9}{|c|}{ Other manufactured products } \\
\hline EP & 1.69 & 2.63 & 2.40 & 2.46 & 2.64 & 1.93 & 2.30 & \multirow{4}{*}{1.36} \\
\hline EPt & 1.06 & 1.86 & 1.60 & 1.54 & 1.75 & 1.32 & 1.45 & \\
\hline EP & 1.04 & 1.75 & 1.56 & 1.49 & 1.76 & 1.30 & 1.39 . & \\
\hline $\mathrm{P}$ & 1.00 & 1.77 & 1.56 & 1.51 & 1.69 & 1.28 & 1.38 & \\
\hline \multicolumn{9}{|c|}{ Total Manufacturing } \\
\hline EP & 1.68 & 2.20 & 2.31 & 2.37 & 2.55 & 2.09 & 2.05 & \\
\hline EPt & 1.08 & 1.62 & 1.60 & 1.54 & 1.74 & 1.46 & 1.34 & \\
\hline EP & 1.03 & 1.49 & 1.51 & 1.46 & 1.72 & 1.39 & 1.29 & \\
\hline $\mathrm{P}$ & 1.00 & 1.50 & 1.46 & 1.47 & 1.68 & 1.39 & 1.26 & \\
\hline ER & 1.00 & 144.79 & 1.61 & 5.43 & 1195.35 & 0.56 & 1.17 & \\
\hline
\end{tabular}

$\mathrm{PE}=$ Expenditure price level

$\mathrm{PEm}=$ Expenditure price level adjusted for wholesale and retail distribution margins.

$\mathrm{PE}^{*}=\mathrm{PEm}$ adjusted for net taxes and subsidies

$\mathrm{OPR}=$ Output price (PE* adjusted for import and export prices)

$\mathrm{UVR}=$ Van Ark-Pilat Unit Value Ratio 
Table 9

Comparison of 1990 Output PPPs with Van Ark-Pilat Unit Value Ratios

\begin{tabular}{|c|c|c|c|c|c|c|}
\hline & Japan & nany & France & Italy & UK & Canada \\
\hline \multicolumn{7}{|c|}{ Food Bevera:ses and Tobacco } \\
\hline OPR & 285 & 1.96 & 7.67 & \multirow{3}{*}{1788} & 0.73 & \multirow{3}{*}{1.67} \\
\hline UVR & 203 & 1.88 & 6.91 & & 0.74 & \\
\hline OPR/UVR & 1.41 & 1.04 & 1.11 & & 0.98 & \\
\hline \multicolumn{7}{|c|}{ Textile, appa el, and leather products } \\
\hline OPR & $335^{\circ}$ & 4.71 & 15.94 & \multirow[t]{3}{*}{2736} & 0.99 & \multirow{3}{*}{1.89} \\
\hline UVR & 186 & 2.71 & 8.05 & & 0.77 & \\
\hline OPR/UVR & 1.80 & 1.73 & 1.98 & & 1.28 & \\
\hline \multicolumn{7}{|c|}{ Chemical, petroleum, rubber, and plastic products } \\
\hline OPR & 208 & 2.25 & 6.18 & \multirow[t]{3}{*}{2246} & 0.75 & \multirow[t]{3}{*}{1.40} \\
\hline UVR & 160 & 2.12 & 6.22 & & 0.54 & \\
\hline OPR/UVR & 1.30 & 1.06 & 0.99 & & 1.38 & \\
\hline \multicolumn{7}{|c|}{ Basic metal industries } \\
\hline UVR & 166 & 2.02 & 6.99 & & 0.66 & \\
\hline \multicolumn{7}{|c|}{ Machinery, equipment, and fabricated metal products, } \\
\hline OPR & 186 & 2.25 & 8.16 & \multirow[t]{3}{*}{1918} & 0.86 & \multirow[t]{3}{*}{1.28} \\
\hline UVR & 123 & 2.14 & 7.41 & & 0.73 & \\
\hline OPR/UVR & 1.52 & 1.05 & 1.10 & & 1.18 & \\
\hline \multicolumn{7}{|c|}{ Other manufactured products } \\
\hline OPR & 256 & 2.52 & 8.20 & \multirow[t]{3}{*}{2016} & 0.72 & \multirow[t]{3}{*}{1.60} \\
\hline UVR & 200 & 2.22 & 6.99 & & 0.90 & \\
\hline OPR/UVR & 1.28 & 1.13 & 1.17 & & 0.80 & \\
\hline \multicolumn{7}{|c|}{ Total Manuf } \\
\hline OPR & 218 & 2.36 & 8.07 & \multirow[t]{4}{*}{2005} & 0.79 & \multirow[t]{4}{*}{1.43} \\
\hline UVR & 157 & 2.14 & 7.10 & & 0.74 & \\
\hline UVR* & 155 & 2.14 & 7.03 & & 0.74 & \\
\hline OPR/UVR & 1.39 & 1.10 & 1.14 & & 1.08 & \\
\hline$\overline{\text { EPPP }}$ & 198 & 2.25 & 7.78 & 1794 & 0.71 & $\overline{1.41}$ \\
\hline GDP PPP & 223 & 2.49 & 7.31 & 1310 & 0.57 & 1.23 \\
\hline ER & 145 & 1.61 & 5.43 & 1195 & 0.56 & 1.17 \\
\hline
\end{tabular}

$\mathrm{OPR}=$ output price ratio

$\mathrm{UVR}=\mathrm{ICOF}$ unit value ratio

$\mathrm{UVR}^{*}=$ Aggregate UVR as computed by ICOP

$E P P P=$ Expenditure purchasing power parity

GDP PPP = ICP PPP for total GDP (EKS method).

$\mathrm{ER}=$ Nominal exchange rate 
Table 10

Productivity

(Output, in 1990 U.S. dollars, per hour)

\begin{tabular}{|c|c|c|c|c|c|c|c|}
\hline 1990 & US & Japan & Germany & France & Italy & UK & Canada \\
\hline Total Manufacturing & 26 & 17 & 21 & 24 & 19 & 16 & 22 \\
\hline Food, Beverages, \& Tobacco & 30 & 11 & 25 & 28 & 30 & 31 & 22 \\
\hline Textiles, Apparel, \& Footwear & 14 & 4 & 8 & 8 & 10 & 7 & 10 \\
\hline Chemical, Petroleum, \& Products & 39 & 49 & 27 & 48 & 19 & 20 & 27 \\
\hline Basic Metals & 28 & 41 & 25 & 27 & 23 & 15 & 22 \\
\hline Machinery, Equip., \& Fab. Metals & 26 & 20 & 23 & 22 & 19 & 12 & 25 \\
\hline Other Manufactured Products & 23 & 12 & 19 & 23 & 19 & 16 & 18 \\
\hline \multicolumn{8}{|l|}{1985} \\
\hline Total Manufacturing & 23 & 13 & 20 & 19 & 16 & 13 & 22 \\
\hline Food. Beverages, \& Tobacco & 29 & 10 & 24 & 26 & 26 & 27 & 22 \\
\hline Textiles. Apparel. \& Footwear & 12 & 4 & 6 & 7 & 10 & 6 & 10 \\
\hline Chemical, Petroleum, \& Products & 32 & 43 & 26 & 29 & 17 & 16 & 28 \\
\hline Basic Metals & 27 & 32 & 23 & 17 & 21 & 11 & 23 \\
\hline Machinery, Equip.. \& Fab. Metals & 21 & 14 & 20 & 18 & 16 & 10 & 23 \\
\hline Other Manufactured Products & 22 & 10 & 17 & 21 & 18 & 14 & 19 \\
\hline \multicolumn{8}{|l|}{1980} \\
\hline Total Manufacturing & 20 & 11 & 17 & 16 & 13 & 10 & 18 \\
\hline Food, Beverages, \& Tobacco & 26 & 12 & 22 & 23 & 22 & 23 & 21 \\
\hline Textiles, Apparel, \& Footwear & 10 & 5 & 5 & 6 & 8 & 5 & 8 \\
\hline Chemical, Petroleum, \& Products & 26 & 25 & 22 & 22 & 13 & 12 & 23 \\
\hline Basic Metals & 27 & 39 & 19 & 16 & 15 & 6 & 18 \\
\hline Machinery, Equip., \& Fab. Metals & 18 & 10 & 18 & 15 & 13 & 8 & 18 \\
\hline Other Manufactured Products & 19 & 8 & 16 & 17 & 16 & 13 & 17 \\
\hline
\end{tabular}


Table 11

Productivity

(Indexed to U.S. Level $=100$ )

\begin{tabular}{|c|c|c|c|c|c|c|c|}
\hline 1990 & US & Japan & Germany & France & Italy & UK & Canada \\
\hline Total Manufiacturing & 100 & 67 & 83 & 94 & 72 & 60 & 83 \\
\hline Food, Beverages, \& Tobacco & 100 & 35 & 84 & 93 & 98 & 102 & 72 \\
\hline Textiles, Apparel, \& Footwear & 100 & 28 & 55 & 57 & 75 & 48 & 72 \\
\hline Chemical, Petroleum, \& Products & 100 & 128 & 70 & 126 & 50 & 51 & 71 \\
\hline Basic Metals & 100 & 145 & 91 & 96 & 81 & 54 & 78 \\
\hline Machinery, Equip., \& Fab. Metals & 100 & 78 & 88 & 87 & 74 & 46 & 97 \\
\hline Other Manufactured Products & 100 & 54 & 81 & 97 & 81 & 70 & 76 \\
\hline \multicolumn{8}{|l|}{1985} \\
\hline Total Manufiacturing & 100 & 59 & 87 & 85 & 73 & 57 & 95 \\
\hline Food, Beverages, \& Tobacco & 100 & 35 & 83 & 87 & 89 & 93 & 76 \\
\hline Textiles, Apparel, \& Footwear & 100 & 38 & 55 & 60 & 84 & 54 & 84 \\
\hline Chemical. Pstroleum, \& Products & 100 & 134 & 83 & 91 & 54 & 51 & 87 \\
\hline Basic Metals & 100 & 121 & 85 & 66 & 78 & 43 & 86 \\
\hline Machinery, Equip., \& Fab. Metals & 100 & 65 & 96 & 87 & 76 & 49 & 110 \\
\hline Other Manufactured Products & 100 & 47 & 76 & 95 & 80 & 65 & 88 \\
\hline \multicolumn{8}{|l|}{1980} \\
\hline Total Manufacturing & 100 & 56 & 85 & 81 & 65 & 50 & 91 \\
\hline Food, Beveriges, \& Tobacco & 100 & 44 & 85 & 86 & 83 & 86 & 79 \\
\hline Textiles, Apparel, \& Footwear & 100 & 51 & 53 & 56 & 81 & 48 & 82 \\
\hline Chemical, Petroleum, \& Products & 100 & 98 & 86 & 85 & 52 & 46 & 88 \\
\hline Basic Metals & 100 & 143 & 69 & 59 & 57 & 22 & 67 \\
\hline Machinery, Equip., \& Fab. Metals & 100 & 55 & 96 & 85 & 68 & 43 & 100 \\
\hline Other Manufactured Products & 100 & 43 & 85 & 91 & 86 & 68 & 92 \\
\hline
\end{tabular}


Table 12

Productivity

(Indexed to total manufacturing $=100$ )

\begin{tabular}{|c|c|c|c|c|c|c|c|}
\hline 1990 & US & Japan & Germany & France & Italy & UK & Canada \\
\hline Total Manufacturing & 100 & 100 & 100 & 100 & 100 & 100 & 100 \\
\hline Food, Beverages, \& Tobacco & 118 & 62 & 119 & 116 & 160 & 200 & 102 \\
\hline Textiles, Apparel, \& Footwear & 53 & 22 & 35 & 32 & 56 & 43 & 46 \\
\hline Chemical, Petroleum, \& Products & 149 & 286 & 126 & 199 & 104 & 126 & 127 \\
\hline Basic Metals & 108 & 235 & 118 & 110 & 122 & 97 & 102 \\
\hline Machinery, Equip., \& Fab. Metals & 99 & 117 & 105 & 92 & 102 & 76 & 116 \\
\hline Other Manufactured Products & 90 & 72 & 88 & 93 & 101 & 105 & 82 \\
\hline \multicolumn{8}{|l|}{1985} \\
\hline Total Manufacturing & 100 & 100 & 100 & 100 & 100 & 100 & 100 \\
\hline Food, Beverages, \& Tobacco & 129 & 76 & 124 & 133 & 158 & 210 & 104 \\
\hline Textiles, Apparel, \& Footwear & 51 & 33 & 33 & 36 & 59 & 48 & 45 \\
\hline Chemical, Petroleum, \& Products & 141 & 319 & 135 & 151 & 105 & 125 & 128 \\
\hline Basic Metals & 117 & 239 & 116 & 91 & 125 & 88 & 106 \\
\hline Machinery, Equip., \& Fab. Metals & 94 & 103 & 104 & 96 & 98 & 81 & 108 \\
\hline Other Manufactured Products & 96 & 77 & 85 & 107 & 106 & 110 & 89 \\
\hline \multicolumn{8}{|l|}{1980} \\
\hline Total Manufacturing & 100 & 100 & 100 & 100 & 100 & 100 & 100 \\
\hline Food, Beverages, \& Tobacco & 132 & 104 & 132 & 141 & 170 & 227 & 114 \\
\hline Textiles, Apparel, \& Footwear & 51 & 47 & 31 & 35 & 63 & 49 & 46 \\
\hline Chemical, Petroleum, \& Products & 131 & 228 & 131 & 139 & 105 & 119 & 126 \\
\hline Basic Metals & 137 & 350 & 111 & 99 & 120 & 59 & 101 \\
\hline Machinery, Equip., \& Fab. Metals & 92 & 90 & 105 & 97 & 97 & 79 & 102 \\
\hline Other Manufactured Products & 94 & 72 & 94 & 107 & 124 & 128 & 96 \\
\hline
\end{tabular}


Table 13

Compensation per Hour

(U.S. dollars per hour)

\begin{tabular}{|c|c|c|c|c|c|c|c|}
\hline 1990 & US & Japan & Germany & & & & \\
\hline Total Manufa:turing & 18 & 15 & 23 & $\frac{\text { France }}{21}$ & Italy & UK & Canada \\
\hline & & & & 21 & 17 & 15 & 17 \\
\hline Food, Beverages, \& Tobacco & 16 & 12 & 17 & 21 & 18 & 14 & 16 \\
\hline Textiles, Apparel, \& Footwear & 10 & 8 & 16 & 16 & 12 & 9 & 12 \\
\hline Chemical. Pet oleum, \& Products & 21 & 25 & 27 & 24 & 21 & 16 & 18 \\
\hline Basic Metals & 21 & 19 & 23 & 18 & 20 & 12 & 19 \\
\hline Machinery, Equip., \& Fab. Metals & 20 & 15 & 24 & 22 & 19 & 13 & 19 \\
\hline Other Manufa:tured Products & 16 & 13 & 20 & 21 & 17 & 15 & 17 \\
\hline \multicolumn{8}{|l|}{1985} \\
\hline Total Manufacturing & 15 & 7 & 10 & 10 & 8 & 7 & 12 \\
\hline Food, Beverages. \& Tobacco & 14 & 6 & 7 & 10 & 8 & 7 & 11 \\
\hline Textiles, Apparel, \& Footwear & 9 & 4 & 7 & 8 & 6 & 5 & 8 \\
\hline Chemical, Petroleum. \& Products & 17 & 12 & 12 & 12 & 10 & 7 & 12 \\
\hline Basic Metals & 18 & 9 & 10 & 10 & 10 & 6 & 15 \\
\hline Machinery, Equip.. \& Fab. Metals & 17 & 8 & 11 & 11 & 9 & 7 & 13 \\
\hline Other Manufactured Products & 13 & 6 & 9 & 10 & 8 & 8 & 12 \\
\hline \multicolumn{8}{|l|}{1980} \\
\hline Total Manufacturing & 11 & 6 & 12 & 12 & 8 & 8 & 9 \\
\hline Food, Beverages, \& Tobacco & 11 & 5 & 10 & 13 & 8 & 8 & 9 \\
\hline Textiles, Apparel, \& Footwear & 7 & 4 & 8 & 9 & 6 & 6 & 6 \\
\hline Chemical. Petroleum, \& Products & 13 & 9 & 15 & 14 & 10 & 9 & 10 \\
\hline Basic Metals & 15 & 9 & 13 & 12 & 10 & 7 & 12 \\
\hline Machinery, Equip., \& Fab. Metals & 12 & 6 & 13 & 13 & 9 & 9 & 10 \\
\hline Other Manufactured Products & 10 & 6 & 11 & 12 & 8 & 9 & 9 \\
\hline
\end{tabular}


Table 14

Compensation per Hour (in dollars) (Indexed to U.S. Level $=100$ )

\begin{tabular}{|c|c|c|c|c|c|c|c|}
\hline 1990 & US & Japan & Germany & France & Italy & UK & Canada \\
\hline Total Manufacturing & 100 & 81 & 126 & 116 & 96 & 80 & 95 \\
\hline Food, Beverages, \& Tobacco & 100 & 77 & 103 & 128 & 109 & 89 & 100 \\
\hline Textiles, Apparel, \& Footwear & 100 & 74 & 150 & 150 & 120 & 90 & 111 \\
\hline Chemical, Petroleum, \& Products & 100 & 118 & 126 & 112 & 99 & 75 & 82 \\
\hline Basic Metals & 100 & 88 & 107 & 84 & 95 & 58 & 89 \\
\hline Machinery, Equip.. \& Fab. Metals & 100 & 76 & 121 & 108 & 93 & 67 & 94 \\
\hline Other Manufactured Products & 100 & 84 & 126 & 132 & 104 & 94 & 105 \\
\hline \multicolumn{8}{|l|}{1985} \\
\hline Total Manufacturing & 100 & 47 & 66 & 70 & 55 & $\overline{48}$ & 80 \\
\hline Food, Beverages, \& Tobacco & 100 & 42 & 54 & 76 & 62 & 50 & 83 \\
\hline Textiles, Apparel, \& Footwear & 100 & 49 & 79 & 88 & 73 & 57 & 91 \\
\hline Chemical, Petroleum. \& Products & 100 & 68 & 70 & 69 & 58 & 42 & 71 \\
\hline Basic Metals & 100 & 50 & 56 & 53 & 54 & 33 & 84 \\
\hline Machinery, Equip., \& Fab. Metals & 100 & 45 & 63 & 66 & 53 & 45 & 78 \\
\hline Other Manufactured Products & 100 & 48 & 65 & 78 & 60 & 57 & 90 \\
\hline \multicolumn{8}{|l|}{1980} \\
\hline Total Manufacturing & 100 & 53 & 109 & 110 & 71 & $\overline{74}$ & 83 \\
\hline Food. Beverages, \& Tobacco & 100 & 46 & 91 & 121 & 77 & 73 & 85 \\
\hline Textiles, Apparel, \& Footwear & 100 & 64 & 125 & 132 & 92 & 86 & 96 \\
\hline Chemical, Petroleum. \& Products & 100 & 70 & 112 & 110 & 76 & 66 & 74 \\
\hline Basic Metals & 100 & 58 & 87 & 80 & 65 & 45 & 82 \\
\hline Machinery, Equip., \& Fab. Metals & 100 & 51 & 107 & 106 & 71 & 70 & 83 \\
\hline Other Manufactured Products & 100 & 55 & 111 & 120 & 76 & 88 & 91 \\
\hline
\end{tabular}


Table 15

Compensation per Hour (in dollars)

\begin{tabular}{l|rrrrrrr}
\hline 1990 \\
\hline Total Manufacturing & US & Japan & Germany & France & Italy & UK & Canada \\
\hline & 100 & 100 & 100 & 100 & 100 & 100 & 100
\end{tabular}

Food. Beveriges. \& Tobacco

Textiles, Apparel, \& Footwear

Chemical, Pttroleum, \& Products

Basic Metals

Machinery. Equip.. \& Fab. Metals

Other Manutactured Products

$\begin{array}{rrrrrrr}89 & 85 & 72 & 98 & 101 & 98 & 93 \\ 58 & 53 & 68 & 75 & 72 & 65 & 68 \\ 118 & 172 & 117 & 113 & 122 & 109 & 102 \\ 119 & 129 & 101 & 85 & 118 & 85 & 111 \\ 112 & 105 & 107 & 104 & 109 & 93 & 110 \\ 88 & 91 & 87 & 100 & 96 & 103 & 97\end{array}$

1985

Total Manufacturing

100

100

100

100

100

100

100

Food. Beverages. \& Tobacco

Textiles. Apparel, \& Footwear

Chemical. Petroleum. \& Products

Basic Metals

Machinery. Equip., \& Fab. Metals

Other Manufactured Products

$\begin{array}{rrrrrrr}91 & 82 & 75 & 99 & 102 & 94 & 94 \\ 57 & 60 & 68 & 72 & 76 & 67 & 65 \\ 116 & 167 & 122 & 116 & 122 & 101 & 103 \\ 122 & 130 & 103 & 93 & 121 & 82 & 128 \\ 111 & 107 & 107 & 105 & 107 & 103 & 108 \\ 88 & 90 & 88 & 99 & 96 & 105 & 99\end{array}$

1980

\begin{tabular}{lrrrrrrr}
\hline Total Manufacturing & 100 & 100 & 100 & 100 & 100 & 100 & 100 \\
& & & & & & & \\
Food. Bevera.zes. \& Tobacco & 94 & 80 & 78 & 104 & 100 & 92 & 95 \\
Textiles. App arel. \& Footwear & 59 & 70 & 67 & 70 & 75 & 68 & 67 \\
Chemical. Petroleum. \& Products & 116 & 152 & 119 & 116 & 123 & 103 & 103 \\
Basic Metals & 133 & 145 & 106 & 96 & 120 & 81 & 131 \\
Machinery, Equip.. \& Fab. Metals & 109 & 104 & 107 & 105 & 108 & 103 & 108 \\
Other Manufactured Products & 90 & 92 & 92 & 98 & 95 & 106 & 98 \\
\hline
\end{tabular}


Table 16

Unit Labor Cost Levels

(Dollars per unit of output)

\begin{tabular}{|c|c|c|c|c|c|c|c|}
\hline 1990 & US & Japan & Germany & France & Italy & UK & Canada \\
\hline Total Manufacturing & 70 & 85 & 106 & 86 & 93 & 93 & 80 \\
\hline Food, Beverages, \& Tobacco & 53 & 116 & 65 & 73 & 59 & 46 & 73 \\
\hline Textiles, Apparel, \& Footwear & 76 & 200 & 207 & 199 & 120 & 142 & 118 \\
\hline Chemical, Petroleum, \& Products & 55 & 51 & 99 & 49 & 108 & 81 & 64 \\
\hline Basic Metals & 77 & 46 & 90 & 67 & 90 & 82 & 87 \\
\hline Machinery, Equip., \& Fab. Metals & 79 & 76 & 109 & 97 & 99 & 113 & 76 \\
\hline Other Manufactured Products & 68 & 107 & 106 & 93 & 88 & 91 & 95 \\
\hline \multicolumn{8}{|l|}{1985} \\
\hline Total Manufacturing & 66 & 53 & 50 & 54 & 50 & 56 & 56 \\
\hline Food, Beverages, \& Tobacco & 46 & 57 & 31 & 40 & 32 & 25 & 50 \\
\hline Textiles, Apparel, \& Footwear & 74 & 94 & 105 & 108 & 65 & 78 & 80 \\
\hline Chemical, Petroleum, \& Products & 55 & 28 & 46 & 41 & 58 & 45 & 45 \\
\hline Basic Metals & 69 & 29 & 45 & 56 & 48 & 53 & 67 \\
\hline Machinery, Equip., \& Fab. Metals & 79 & 54 & 52 & 60 & 54 & 71 & 55 \\
\hline Other Manufactured Products & 61 & 62 & 52 & 50 & 45 & 54 & 62 \\
\hline \multicolumn{8}{|l|}{1980} \\
\hline Total Manufacturing & 57 & 54 & 73 & 77 & 63 & 84 & 52 \\
\hline Food, Beverages, \& Tobacco & 40 & 42 & 43 & 57 & 37 & 34 & 43 \\
\hline Textiles, Apparel, \& Footwear & 66 & 82 & 156 & 154 & 75 & 117 & 77 \\
\hline Chemical, Petroleum, \& Products & 50 & 36 & 66 & 65 & 74 & 73 & 43 \\
\hline Basic Metals & 55 & 22 & 69 & 75 & 63 & 115 & 68 \\
\hline Machinery, Equip., \& Fab. Metals & 67 & 62 & 74 & 84 & 69 & 109 & 55 \\
\hline Other Manufactured Products & 54 & 69 & 71 & 71 & 48 & 70 & 54 \\
\hline
\end{tabular}


Table 17

Unit Labor Cost Levels

(Indexed to U.S. Level $=100$ )

\begin{tabular}{|c|c|c|c|c|c|c|c|}
\hline 1990 & US & & & & & & \\
\hline Total Manufacte ring & 100 & 121 & $\frac{\text { Germany }}{152}$ & $\frac{\text { France }}{124}$ & $\frac{1 \text { taly }}{133}$ & $\frac{U K}{134}$ & $\frac{\text { Canada }}{115}$ \\
\hline Food, Beverages, \& Tobacco & 100 & 220 & 123 & 137 & & & \\
\hline Textiles, Apparel, \& Footwear & 100 & 265 & 274 & 263 & 111 & 87 & 138 \\
\hline Chemical, Petroleum, \& Products & 100 & & & 263 & 159 & 188 & 156 \\
\hline Basic Metals & & 92 & & 89 & 196 & 147 & 116 \\
\hline Machinery, Equip., \& Fab. Metals & & 61 & 118 & 88 & 118 & 107 & 114 \\
\hline Other Manufactt red Products & 100 & 97 & 138 & 124 & 126 & 144 & 97 \\
\hline & 100 & 157 & 154 & 136 & 129 & 134 & 138 \\
\hline \multicolumn{8}{|l|}{$\frac{1985}{-}$} \\
\hline Total Manufactu ing & 100 & 79 & 76 & 82 & 76 & 85 & $\overline{84}$ \\
\hline Food, Beverages \& Tobacco & 100 & 122 & 66 & 87 & 70 & 54 & 108 \\
\hline Textiles, Appare], \& Footwear & 100 & 128 & 142 & 146 & 88 & 105 & 109 \\
\hline Chemical, Petrolıum, \& Products & 100 & 50 & 84 & 76 & 107 & 83 & 82 \\
\hline Basic Metals & 100 & 41 & 65 & 81 & 70 & 76 & 97 \\
\hline Machinery, Equi|)., \& Fab. Metals & 100 & 69 & 66 & 76 & 69 & 91 & 71 \\
\hline Other Manufactu -ed Products & 100 & 102 & 85 & 82 & 74 & 88 & 102 \\
\hline \multicolumn{8}{|l|}{1980} \\
\hline Total Manufacturing & 100 & 95 & 128 & 136 & 110 & 147 & $\overline{92}$ \\
\hline Food, Beverages, \& Tobacco & 100 & 103 & 106 & 141 & 92 & 84 & 108 \\
\hline Textiles, Apparel \& Footwear & 100 & 124 & 236 & 234 & 114 & 178 & 117 \\
\hline Chemical, Petroleum, \& Products & 100 & 72 & 131 & 129 & 146 & 144 & 85 \\
\hline Basic Metals & 100 & 41 & 126 & 136 & 114 & 208 & 123 \\
\hline Machinery. Equif.. \& Fab. Metals & 100 & 93 & 111 & 125 & 104 & 163 & 83 \\
\hline Other Manufactured Products & 100 & 127 & 131 & 131 & 88 & 129 & 99 \\
\hline
\end{tabular}


Table 18

Unit Labor Cost Levels

(Indexed to total manufacturing $=100$ )

\begin{tabular}{|c|c|c|c|c|c|c|c|}
\hline 1990 & US & Japan & Germany & France & Italy & UK & Canada \\
\hline Total Manufacturing & 100 & 100 & 100 & 100 & 100 & 100 & 100 \\
\hline Food, Beverages, \& Tobacco & 76 & 137 & 61 & 84 & 63 & 49 & 91 \\
\hline Textiles, Apparel, \& Footwear & 108 & 237 & 195 & 231 & 129 & 152 & 147 \\
\hline Chemical, Petroleum, \& Products & 79 & 60 & 93 & 57 & 117 & 87 & 80 \\
\hline Basic Metals & 110 & 55 & 85 & 78 & 97 & 87 & 109 \\
\hline Machinery, Equip., \& Fab. Metals & 113 & 90 & 102 & 113 & 107 & 121 & 95 \\
\hline Other Manufactured Products & 98 & 127 & 99 & 108 & 95 & 98 & 118 \\
\hline \multicolumn{8}{|l|}{1985} \\
\hline Total Manufacturing & 100 & 100 & 100 & 100 & 100 & 100 & 100 \\
\hline Food, Beverages, \& Tobacco & 70 & 108 & 61 & 75 & 65 & 45 & 91 \\
\hline Textiles. Apparel, \& Footwear & 112 & 179 & 209 & 198 & 129 & 139 & 145 \\
\hline Chemical, Petroleum, \& Products & 82 & 52 & 91 & 76 & 116 & 81 & 81 \\
\hline Basic Metals & 104 & 54 & 89 & 102 & 97 & 94 & 120 \\
\hline Machinery, Equip., \& Fab. Metals & 119 & 103 & 102 & 110 & 109 & 127 & 100 \\
\hline Other Manufactured Products & 92 & 118 & 103 & 92 & 90 & 96 & 112 \\
\hline \multicolumn{8}{|l|}{1980} \\
\hline Total Manufacturing & 100 & 100 & 100 & 100 & 100 & 100 & 100 \\
\hline Food. Beverages, \& Tobacco & 71 & 77 & 59 & 73 & 59 & 40 & 83 \\
\hline Textiles. Apparel, \& Footwear & 116 & 150 & 214 & 199 & 120 & 140 & 147 \\
\hline Chemical, Petroleum, \& Products & 88 & 66 & 91 & 84 & 117 & 87 & 81 \\
\hline Basic Metals & 97 & 41 & 95 & 97 & 101 & 137 & 130 \\
\hline Machinery, Equip., \& Fab. Metals & 118 & 115 & 102 & 108 & 111 & 130 & 106 \\
\hline Other Manufactured Products & 95 & 127 & 98 & 92 & 76 & 83 & 102 \\
\hline
\end{tabular}




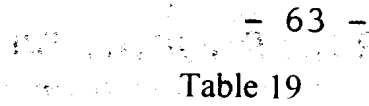

Alternative Estimates of Unit Labor Cost Levels for Total Manufacturing (Indexed to U.S. Level $=100$ )

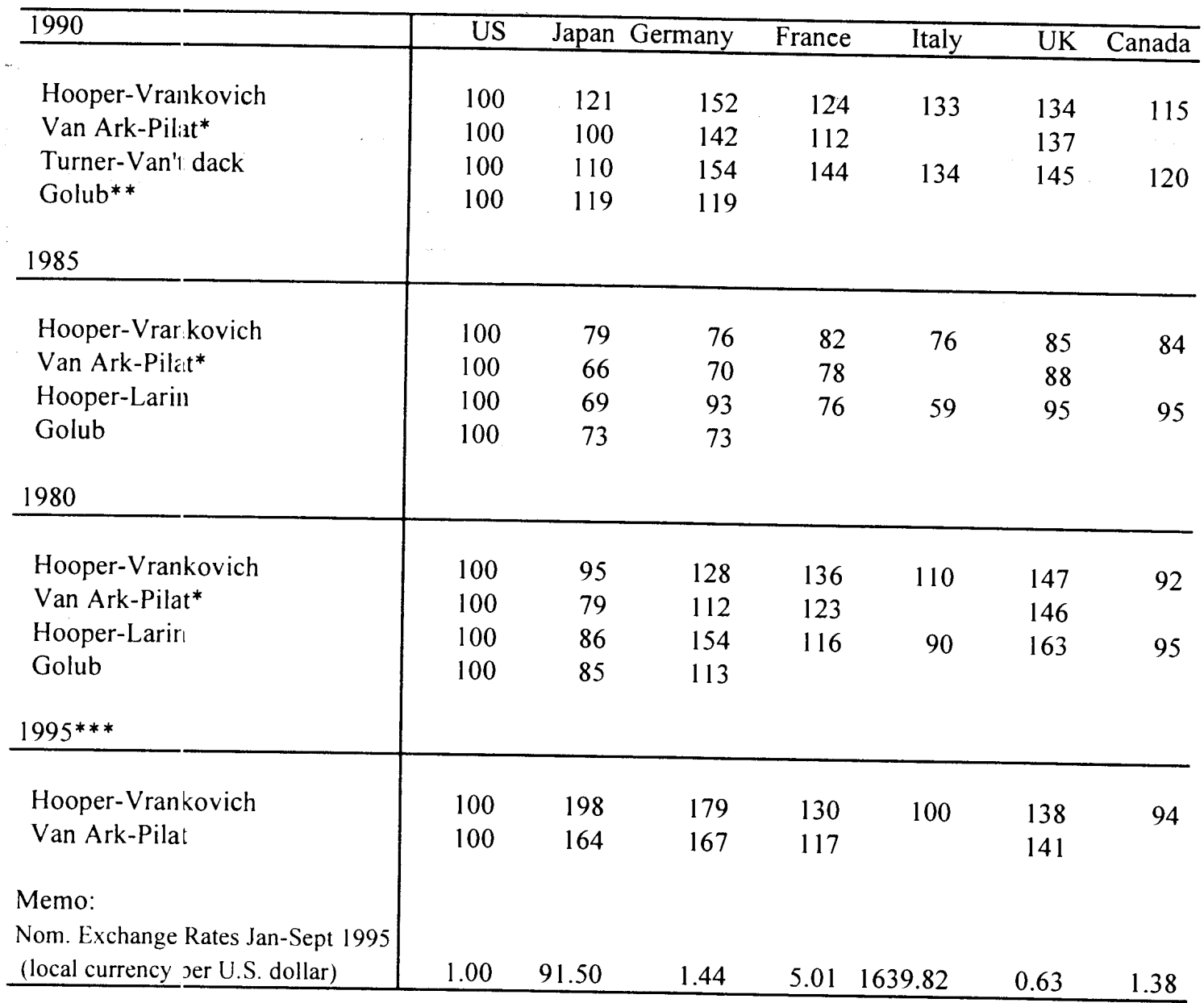

* Van Ark (1995)

** Data are for 1989

*** Estimates are extrapolated from 1990 levels using BLS and IMF unit labor cost indexes through 1994 and earl 1995 (held constant after their latest values), and nominal exchange rates through January-September I995. 

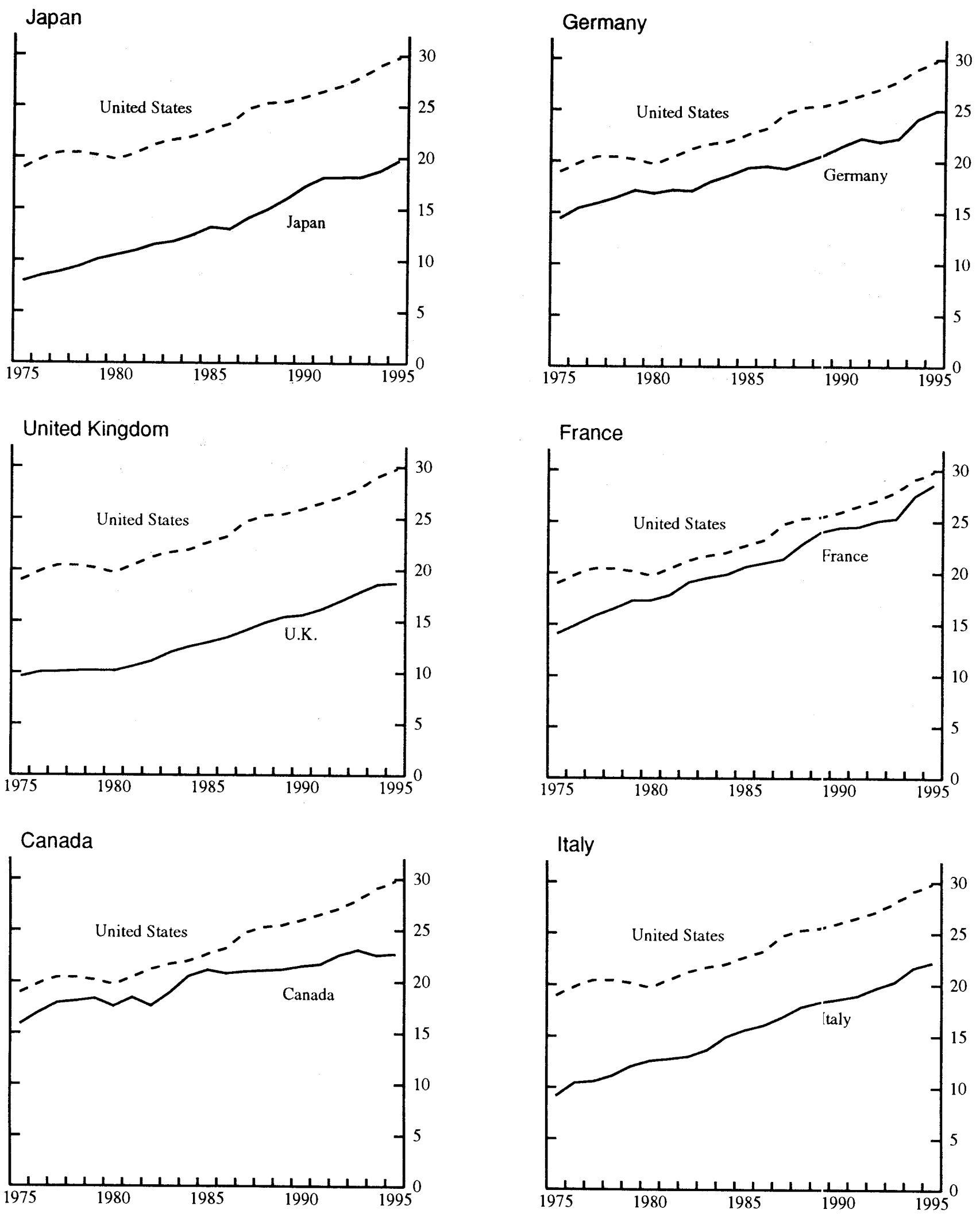

* Non-U.S. data translated to dollars using 1990 OPRs. 


\section{COMPENSATION PER HOUR OF MANUFACTURING EMPLOYEES}
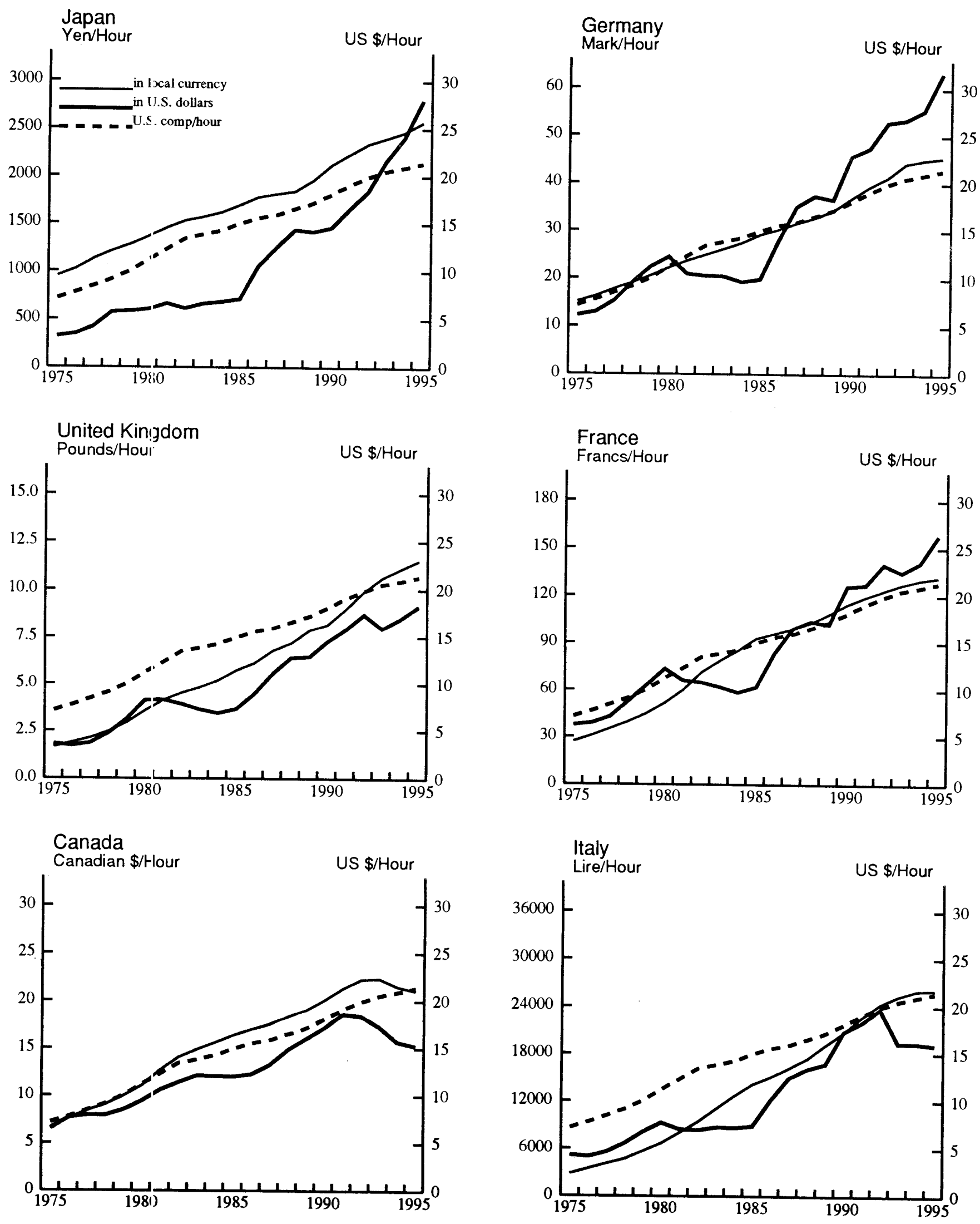


\section{$-66-$}

\section{MANUFACTURING UNIT LABOR COSTS \\ (Dollars per unit of output) ${ }^{*}$}
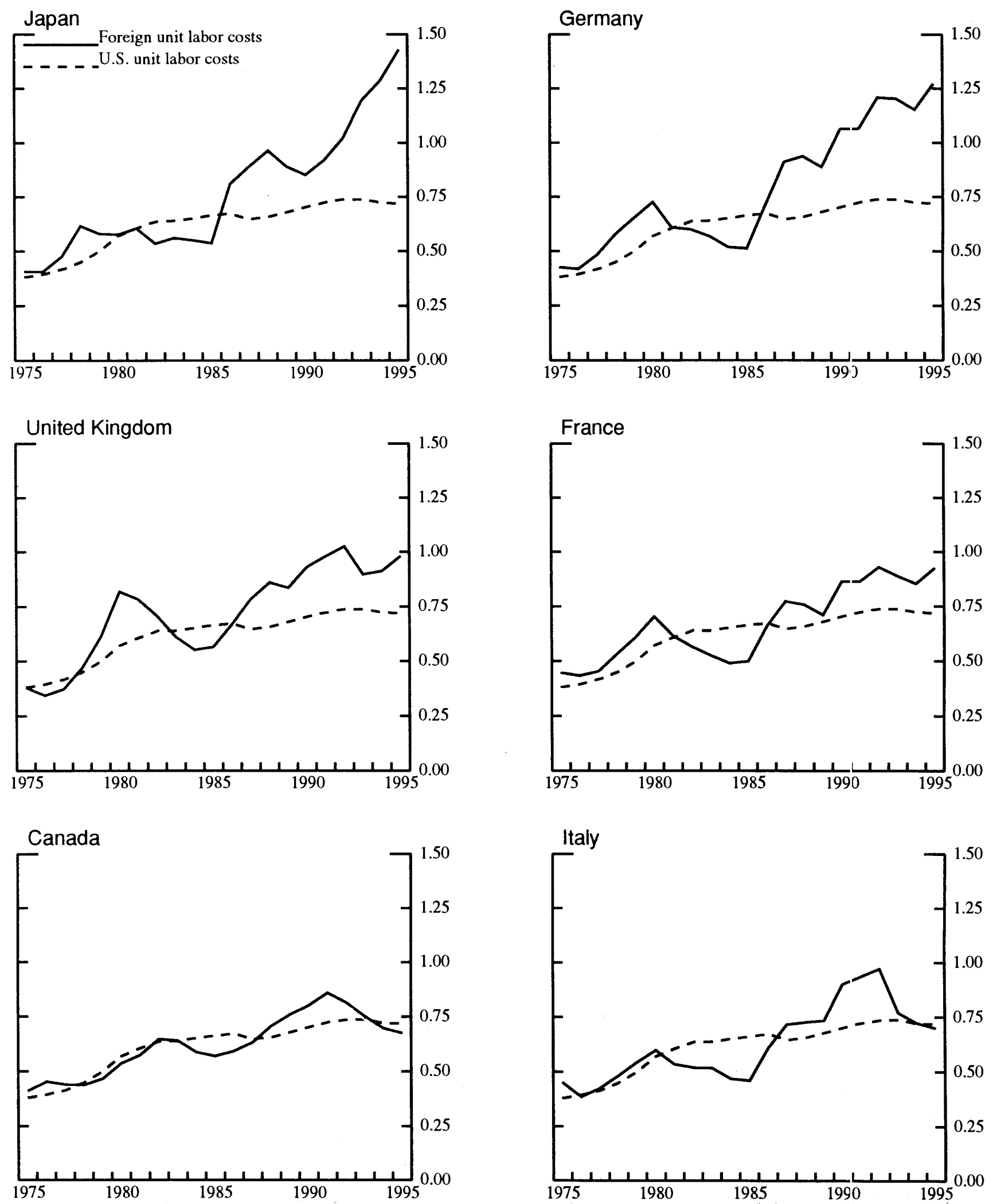


\section{International Finance Discussion Papers}

IFDP

Number
Titles

1995

527 International Comparisons of the Levels of Unit Labor Costs in Manufacturing

526 Uncertainty, Instrument Choice, and the Uniqueness of Nash Equilibrium: Microeconomic and

Macroeconomic Examples

525 Targeting Inflation in the 1990s: Recent Challenges

524 Economic Development and Intergenerational Economic Mobility

$523 \quad$ Human Capital Accumulation, Fertility and Growth: A Re-Analysis

522 Excess Returns and Risk at the Long End of the Treasury Market: An EGARCH-M Approach

521 The Money Transmission Mechanism in Mexico

$520 \quad$ When is Monetary Policy Effective?

519 Central Bank Independence, Inflation and Growth in Transition Economies

518 Alternative Approaches to Real Exchange Rates and Real Interest Rates: Three Up and Three Down

517 Product market competition and the impact of price uncertainty on investment: some evidence from U.S. manufacturing industries

$516 \quad$ Block Distributed Methods for Solving Multi-country Econometric Models

515 Supply-side sources of inflation: evidence from OECD countries
Author(s)

Peter Hooper

Elizabeth Vrankovich

Dale W. Henderson

Ning S. Zhu

Richard T. Freeman

Jonathan L. Willis

Murat F. Iyigun

Murat F. Iyigun

Allan D. Brunner

David P. Simon

Martina Copelman

Alejandro M. Werner

John Ammer

Allan D. Brunner

Prakash Loungani

Nathan Sheets

Hali J. Edison

William R. Melick

Vivek Ghosal

Prakash Loungani

Jon Faust

Ralph Tryon

Prakash Loungani

Phillip Swagel International Finance, Stop 24, Board of Governors of the Federal Reserve System,
Washington, D.C. 20551. 


\section{International Finance Discussion Papers}

IFDP

Number

513 Bank Lending and Economic Activity in Japan:

Did "Financial Factors" Contribute to the Recent Downturn?

512 Evidence on Nominal Wage Rigidity From a Panel of U.S. Manufacturing Industries

Titles

1995

Capital Flight from the Countries in Transition:

Some Theory and Empirical Evidence

Do Taxes Matter for Long-Run Growth?: Harberger's Superneutrality Conjecture

Options, Sunspots, and the Creation of Uncertainty

Hysteresis in a Simple Model of Currency Substitution

Import Prices and the Competing Goods Effect

Supply-side Economics in a Global Economy

The Lucas Critique In Practice: Theory Without Measurement

Real Exchange Rate Targeting and Macroeconomic Instability

Inferences from Parametric and Non-Parametric

Covariance Matrix Estimation Procedures

Exchange-Rate Based Inflation Stabilization: The Initial Real Effects of Credible Plans

Strategic Returns to International

Diversification: An Application to the Equity

Markets of Europe, Japan, and North America

Real Exchange Rate Movements in High Inflation Countries
Author(s)

Nathan Sheets

Allan D. Brunner Steven B. Kamin

Vivek Ghosa:

Prakash Loungani

Enrique G. Mendoza Gian Maria Milesi-Ferretti Patrick Asea

David Bowman

Jon Faust

Martin Uribe

Phillip Swage:l

Enrique G. Mendoza

Linda L. Tesar

Neil R. Ericsson

John S. Irons

Martin Uribe

Wouter J. Den Haan

Andrew T. Levin

Martin Uribe

John Ammer

Jianping Mei

John H. Rogers

Ping Wang 